\title{
Ethical requirement and financial interest: a literature review on socially responsible investing
}

\author{
Miriam von Wallis $\cdot$ Christian Klein
}

Received: 9 July 2012/Accepted: 24 March 2014/Published online: 28 October 2014

(C) The Author(s) 2014. This article is published with open access at Springerlink.com

\begin{abstract}
This paper provides an overview of the status quo in socially responsible investing (SRI) literature. We outline motives, history, and current best practice of SRI. We also provide a thorough analysis of a wide set of studies that cover two key topics in this field: the first research objective is to determine the relative performance of SRI vehicles in comparison to their conventional benchmarks. Our metaanalysis shows that most research studies find that socially responsible (SR) investments perform equal to conventional investments, but these findings are challenged by contradictory results from other studies. The second objective is to analyze SR behavior's effects on a company's financial results. We cover the period between 1986 and 2012. This paper provides future researchers with a well-documented and structured overview of the existing literature on SRI, thereby identifying gaps that might be closed by future research.
\end{abstract}

Keywords Socially responsible investing $\cdot$ SRI $\cdot$ Socially responsible investment · Ethical investment · Corporate social responsibility · Investment screens - Sustainable investments - Financial performance - Business ethics - Socially responsible rating approach

JEL Classification $\quad$ M14 $\cdot$ G11

Responsible editor: Engelbert Dockner (Finance).

\footnotetext{
M. von Wallis

Munich, Germany

e-mail: miriam.vonwallis@gmail.com

C. Klein $(\bowtie)$

Department of Corporate Finance, University of Kassel, Henschelstraße 4, 34109 Kassel, Germany e-mail: klein@uni-kassel.de
} 


\section{Introduction}

An increasing interest in socially responsible investing (SRI) and ethical decisions in finance, especially in the context of the most recent financial crisis, can be seen in both public discussions and the academic literature. As Prodhan (1995:21) notes "unethical practices in the finance domain have become a common occurrence in the late twentieth century, reflecting the spirit of the times." Many private investors as well as institutional investors want to counteract such developments and seek to combine their financial and social interests.

This is reflected in the large amounts invested according to SRI principles. For the beginning of 2010, the Social Investment Forum Foundation (2010) reports a total of \$3.07 trillion in SR investments in the USA. Its European counterpart, the Eurosif (2010), reports a total of $€ 5$ trillion in such investments. They split the figure into $€ 1.2$ trillion invested in core and the remaining $€ 3.8$ trillion into broad SR investments. The latter includes funds performing simple screening methods, while core investments cover funds using more complex screening methods. In their European study, they include 19 countries: Austria, Belgium, Cyprus, Denmark, Estonia, Finland, France, Germany, Greece, Italy, Latvia, Lithuania, The Netherlands, Norway, Poland, Spain, Sweden, Switzerland, and the UK. In addition, Renneboog et al. (2008) provide an overview of the increases in SR investments for the US, European, Canadian, and Australian markets over time. This serves as proof of the interest investors have in combining financial and ethical motives.

We now have the benefit of more than 40 years of academic research on SRI and its impact, and want to provide the reader with a complete overview of the respective literature, as well as to point out the state-of-the-art research methods in this field. We provide a well-structured overview of an extensive set of studies on SRI and their results. Our main focus is on the question whether or not this is a financially rewarding investment approach. This serves as an ideal starting point for future research in this area.

The rest of this paper is organized as follows. In the next section, we address the development of SRI over time and provide an overview of different terms and scholars' definitions. We also identify the motives of different investor groups to include SR action in their investment decisions. This section ends with an explanation of different methods and, how these motives can be put into practice. In Sect. 3 we cover two major questions in the academic literature: first, if SR investments financial performance compares favorably to conventional investments, this would motivate investors to act in a SR manner. Second, does SR behavior pay out for the companies themselves? We also provide an overview of the different methods and parameters, as well as the regional focus and the covered time frame of our empirical research study set. In Sect. 4 we address more recently discussed fields of research, such as SR investment ratings and multi-attribute portfolio optimization. We conclude by summarizing our results and providing an overview of potentially interesting future research topics. 


\section{SRI development, motives, and current implementation}

\subsection{Historical development}

Since the early biblical times, Jewish law set out the first specific rules for ethical investment. In the mid-1700s, the Methodist Church sought to do the same (Schueth 2003). As early as 1948, UK church investors established their own investment portfolios considering ethical constraints (Sparkes 2002:27). In the 1900s, the equity market started to focus more on the specific religious requirements of the Islamic community, for example, excluding specific sectors like pork production (Renneboog et al. 2008) from investment portfolios. Another specific aspect of Islamic banking is the abandonment of the fixed-income market, since receiving and paying interest rates are not permitted (Hussein and Omran 2005). Furthermore, a growing environmental movement has raised its concerns (Fowler and Hope 2007). More recently, personal ethical and social convictions have become more important. For example, the Pax World Fund was founded to ban investments in the production of weapons, due to the Vietnam War. Other funds excluded investments in South Africa during the apartheid regime. Chernobyl and the Exxon Valdez disaster increased awareness of negative environmental consequences, thereby influencing investment habits (Renneboog et al. 2008). Investment decisions initially followed a simple triangle, covering liquidity, risk, and return. Nowadays, an increasing number of investors use the magical square: liquidity, risk, return, and sustainability. This can be seen as an enhancement of the neoclassical homo economicus, who is driven only by economics, as displayed in Fig. 1 (Cengiz et al. 2010).

\subsection{Terminology}

There is much heterogeneity in the current academic literature concerning agreedupon terminology for the above-mentioned movements. While Cowton (1999) summarizes the discussion on how to refer to these investment types as a "matter of taste," Dorfleitner and Utz (2012) do not see the need for a general definition of SRI, stating that sustainability means something different for every individual investor, and that sustainable investments sufficiently summarize every desirable non-financial impact an investment may have. Nevertheless, scholars have sought to find an appropriate terminology. Typical terms used are SRI, ethical investing, or value-based investing (Sandberg et al. 2009). Ethical investing is the oldest phrase, which is slowly being replaced by SRI (Sparkes 2001). Although the terms are inconsistent in the academic literature, Sandberg et al. (2009) find that definitions of SRI are consistent in that it means the "integration of certain non-financial concerns, such as ethical, social or environmental, into the investment process." This paper follows the broader majority of research and uses the term SRI. While this term defines the active task of investing in a SR manner, the term corporate social responsibility (CSR) is used in the academic literature to describe a company's ethical and responsible behavior. It describes companies that integrate social and ecological topics into their corporate governance (Pinner 2003:87). By implementing CSR, the companies establish a basis for SR investors, to consider 

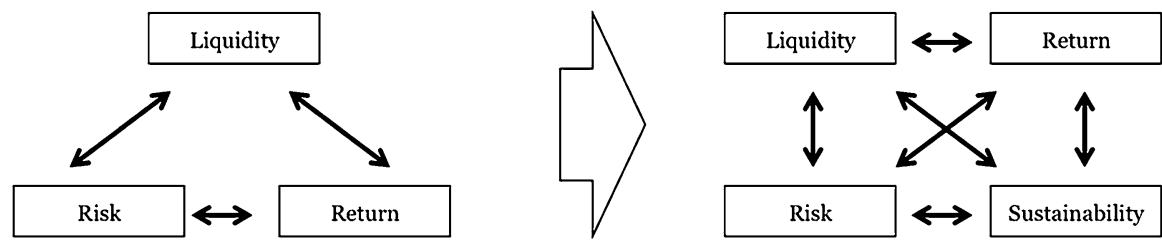

Fig. 1 Investor needs in the investment process: Cengiz et al. (2010)

their company as a potential investment. Or vice versa, the shareholders use their voting rights to move the company's management in a more SR direction (Sparkes and Cowton 2004).

\subsection{Motivation}

Among private investors, the increase in SR investments over the past decade can be referred to as "grassroots pressures," which means it is driven by consumer preferences rather than being "cooked up by Wall Street" (Schueth 2003). These preferences can be guided by simple financial motives, whether SRI can provide a better performance than conventional investments would do, a discussion covered in great length in the next section of this paper. Pasewark and Riley (2010) link the preference of some private investors for SRI to the fact that private investors seek investments consistent with their personal values, which can be driven by religious or political beliefs. The Bischofskonferenz (2010) provides an overview of ethical investments and encourages their members to follow a SRI approach, although they emphasize that not all investments might be suitable for each household. They also stipulate that the Christian church itself must adhere to SRI standards when investing its money. In their study, Lu and Chan (2012) examine the impact of religious attendance and portfolio selection. They find that religious attendance is positively related to stock returns and can result in declining demand for risky asset investments. An explanation for this might be that religious investors have less money to allocate; because they have less working hours due to attendance of religious events and that they donate some of their money. Lewis and Mackenzie (2000b) perform a study on the motives of SR investors and show that most of them are driven by the wish to avoid harmful companies (84\%), while $73 \%$ aim to support companies with a positive impact on society, followed by $69 \%$ that simply state that they want their investments to be ethically clean. In their empirical study, McCann et al. (2003) find evidence of a new ethical discourse from investors seeking to move away from the "hard-nosed form of capitalism" and globalization. While the initial discussion held that only certain niche investors consider ethical behavior in their investment decisions, the shared understanding in the literature is now that considerable growth has taken place in the past years and that SRI has begun to "enter the mainstream of investment practice" (Sparkes and Cowton 2004). Sparkes (2002:86) concludes that although both groups of investors are driven by different motives, conventional investors and SR investors share certain concerns. The question is: has investment behavior changed, or are we seeing a new generation of investors? Rosen et al. (1991) examined 4,000 individual investors in 
SRI funds and find that their average investor is younger and better educated than the average conventional investor, and that while these investors focus on environmental and labor issues, they are unwilling to sacrifice financial returns to support SR behavior. Michelson et al. (2004) also mention changes in education as an explanatory factor for increasing SR investments. This is also supported by Sparkes (2002:86), who finds that SR investors are well educated and have above average incomes, and concludes that they probably work in a caring profession. Lewis and Mackenzie (2000a) perform a study on over 1,000 investors and find that they are "neither cranks nor saints", but rather middle-aged people, with average income situations, who actively support social activist groups. The previous findings that SR investors are younger and better educated can also not be confirmed by McLachlan and Gardner (2004) who survey 109 Australian investors. Besides private investors, institutional investors also seem to be moving to SRI. "Many institutional investors have explicitly adopted the promotion of environmental, social and good corporate governance compliant investing into their investment policy (Risklab 2009)." However, there might be different motives behind this effort, compared to private investors. Institutional investors such as financial institutions must consider the effect an introduction of SRI would have on their company value, because their main goal is usually shareholder value maximization.

But investors-private and institutional—are only one group that might be interested in SR action. The second group consists of the target companies themselves and their motives to steer their companies in accordance with SR principles. Hong and Kacperczyk (2009) prove that the so called "sin" companies are punished by capital markets, due to the higher cost of capital they have to pay to finance themselves. This would be an incentive to act more SR. They argue, however, that although this might be an option for polluting companies, which might be able to improve their production processes, companies that produce alcohol, tobacco, or are engaged in gambling are charged higher cost of capital due to their underlying business, which leaves little room for improvement. Heinkel et al. (2001) show in their paper that SRI can force companies to change their behavior. They prove this by setting up a simple equilibrium model which shows that a company which uses a polluting technology is confronted with rising cost of capital if a significant number of SR investors divest from this firm. The remaining investors then demand higher returns for holding larger shares in the polluting company than initially intended. They find support that the currently small number of SR investors is not decisive to change a company's business approach. However, a doubling of the number of SR investors might trigger a change in companies' SR behavior. The advantage SR behavior might have on a company's valuation is also addressed by Aktas et al. (2011), who analyze SR behavior in the context of mergers and acquisitions. They find that the higher the level of SRI implementation on the target's side, the higher are the gains of the acquiring company. One explanation they offer for this is the ability the target has to learn from the SRI experience. This of course only adds value, if the implemented SRI strategies are really "value enhancing". Renneboog et al. (2008) analyze whether or not companies should be SR. They explain that, from a "textbook financial approach," if all companies maximize their own profits, resource allocation should be pareto-optimal and social 
welfare would be maximized. This is supported by the Friedman argument that companies should care only about profits and let the government deal with externalities. Friedman (1970) argues first that a SR manager spends someone else's money (e.g., that of shareholders, customers, and employees) for social causes. He further questions the manager's right to decide which social cause to support. However, more recent economic theory proves that social welfare might not be maximized if some externalities (e.g., environmental pollution) are not priced at all. They conclude that, in practice, the maximization of shareholder value often conflicts with the consideration of SR behavior, and that stakeholder-value maximization should be strived for (Renneboog et al. 2008). This conflict of interest between stakeholder and shareholder can be resolved in two ways: one approach would be to only perform CSR methods that also increase the present value of the company's future cash flows. These would be measures that avoid costly government-imposed fines, or reduce risk exposure (Mackey et al. 2007). It can be shown that introducing CSR reduces the costs of conflicts between corporations and society. In terms of product sales, CSR is in line with profit maximization, because only ethical consumers will buy ethical brands, so no adverse welfare effect should be expected (Rennebooget al. 2008). The other approach would be to also implement measures that reduce a company's future cash flows, so-called costly philanthropy (Mackey et al. 2007). This argument is reviewed by Allen et al. (2007) in a more global approach; they show that stakeholder-oriented societies have higher company values than shareholderoriented societies, which serves as proof of CSR's compatibility with shareholder gain maximization. Finally, Rivoli (2003) provides an interesting logic for the link between SRI and company valuation: She argues that companies might want to be screened in the positive group, rather than being screened out due to unethical behavior. She points out that if a company's share price increases, due to the fact that the company has been screened into a SRI fund, then it can be concluded that, if firms care about their share price, they will seek to act in a way that ensures positive screening. Rivoli (2003) cites various financial papers and concludes that, from different perspectives, financial markets are not perfect, but rather imperfect. Due to these imperfections, various empirical studies have shown that a larger investor base relates positively to the company share price. Therefore, being screened as positive and thereby also attracting SR investors is the preferable path to follow. Other arguments for companies to engage in CSR include the positive signaling effect, which can increase a company's quality or reputation (Fombrun and Shanley 1990; Friedman and Miles 2001), increase trust in its providing qualitative products (Fisman et al. 2006), or attract motivated workers (Brekke and Nyborg 2004). Another reason for introducing CSR into a company might be pressure from social and environmental lobbyists (Baron 2001; Friedman and Miles 2001). Moskowitz (1997) provides some examples of company behavior that was perceived as unethical by the general public that forced the companies into action. Pressure might also result from the introduction of stricter regulations and guidelines by governments. Friedman and Miles (2001) provide background information on why the interest in SRI has been increasing in the UK, indicated by the launch of the FTSE4Good index in July 2001, triggered by the publication of new pension 
regulations in the UK in July 2000 which state that all private sector pension funds must incorporate SRI and voting rights into their overall investment policy. It is important to point out that the pension funds are not forced to invest according to SRI principles, but instead must state the extent to which they consider such principles (Sparkes 2001). Renneboog et al. (2008) provide an overview of SRIrelated regulations worldwide. Contrary to the results of Friedman and Miles (2001), Cox et al. (2004) find "at best" a limited influence of regulatory actions on the consideration of SRI in pension funds. Finally, some managers might overimplement CSR strategies for their private benefit, so as to improve their reputations and to be seen as more moral managers (Barnea and Rubin 2010). A contradicting new look on the link between CSR projects and a firm's financial performance is taken by Hong et al. (2012), who point out a reverse causality between both. They stipulate that there are no free lunches in "corporate goodness", meaning that it needs companies with a certain financial power to implement CSR projects, as these come at certain costs. They state that a company's result does not improve by introducing CSR projects (and thereby "doing well by doing good"), but rather companies which are financially performing well spend more on CSR projects. They find proof for this theory by investigating the SR-related spending of companies during the Internet bubble of 1996-2000, showing that at a time where more funds were available to the companies, the companies did improve their CSR efforts.

The reasons for SRI by private and institutional investors as well as the abovementioned companies are diverse and complex. Although it is not yet agreed in the academic literature that one of these reasons is the main driver of the extensive interest in SRI, or whether it is a combination of the above-mentioned reasons that leads to more SRI, the increasing amounts of money invested according to SRI principles is proof of this increased interest.

\subsection{Current implementation}

Generally speaking, ethical investors have the same asset class universe than conventional investors: they can invest in equity, fixed income products, and alternative investments. Most SR investors (84\%) tend to use discretionary mandates for their asset management, while only $14 \%$ use investment funds (Eurosif 2010). The paradox in SRI is that “one person's taboo is another person's sacred cow" (Gasparino and Tam 1998). In this regard, Dunfee (2003) cites the simple example that the Islamic Amana Fund and the Ave Maria Catholics Value Fund naturally appeal to different ethical investors. As different investors look for different ethical funds, distinct methods to determine what is ethical become necessary. Sandberg et al. (2009) discuss the heterogeneity of how non-financial concerns can be integrated into the investment process. They discuss positive and negative screening, shareholder activism and community development investing, and provide a list of strategies discussed in the academic literature. The distinction between screening, shareholder advocacy, and community investing is also made by Schueth (2003). Sparkes (2002:29) mentions avoidance, targeting positive activities, shareholder activism, best-in-class, industries of the future, and SRI risk 
optimization. In the remainder of this section we follow the classification by Domini (1992:5), who posits three different ways of social investing: guideline portfolio investment, shareholder activism, and community development investing.

\subsubsection{Guideline portfolio investment}

There are various possibilities of how guidelines can be set in a portfolio. We will discuss the two most widely accepted ones: the screening approach and the best-inclass approach.

2.4.1.1 Screening approach Screening can be defined as "a criterion applied to a universe of potential investments that helps winnow the candidates" (Kinder and Domini 1997). In the academic literature, a distinction is made between positive and negative screening. Renneboog et al. (2008) find that most SRI mutual funds use more than one screen to determine their portfolio. They mention that $64 \%$ of these funds in the USA use more than five screens, while $18 \%$ use only one screen.

When church organizations began to invest according to SRI principles, the avoidance of "sin stocks"-gambling, alcohol, and tobacco-became a topic (Cowton 1998), giving rise to negative screening. The traditional negative social investment screens include military contracting, alcohol and tobacco, gambling, and nuclear power (Kinder and Domini 1997). Furthermore, a company's environmental record, product quality, attitude toward consumers, corporate citizenship, employee relations, and cultural diversity might also be screened (Camey 1994). Some studies also mention political donations and oppressive government regimes (Luther et al. 1992). For an explanation on the different screening possibilities offered by the Social Investment Forum, see also Barnett and Salomon (2006). According to negative screening or avoidance, companies with specific characteristics are excluded from consideration (Camey 1994; Cowton 1998; Bischofskonferenz 2010; Renneboog et al. 2008). This approach is criticized among others by Schwartz (2003), who questions whether all negative ethical screens - for example, gambling screens-are really ethical screens. He argues that for most "questionable" industries, negative as well as positive effects can be put in place. Regarding, for example, the gambling industry, the majority of the US society nowadays accepts gambling as leisure-time activity. He opts for implementing explicit codes of ethics, rather than performing screens that "reflect intended investor's social, religious, or political attitudes and beliefs, which are not necessarily ethically justified." Another obstacle in screening is defining which companies one really wants to exclude from a portfolio, when applying this screen. A good example is Cowton (1995:222), who provides an overview of how different funds understand the screening approach for military contracts. Some ban all involvement in arm trade, but others only the manufacturing or the distribution of arms. One can also distinguish between funds that exclude only those companies with a substantial interest in military contracts, whereas others might also exclude a company with a small foreign subsidiary that produces strategic items such as radar equipment from their portfolios (Cowton 1995:222). 
The positive approach or positive screening means that investments are only made in companies that meet specific criteria (Camey 1994; Cowton 1998). The purpose of this is to encourage and assist SR behavior in companies (Bischofskonferenz 2010). Richardson (2009) criticizes the ethical screening approach. He notes that, "in a milieu where SRI is largely a matter of voluntary choice," some financiers only "masquerade" as responsible investors without really changing their underlying unethical practices. Initially, ethical investments were driven primarily by moral desire and the perceived responsibility to improve the world, whereas today SRI is mainly driven by the desire to increase returns, and/or to reduce investment risk. Therefore, he advocates increased governmental regulation in the SRI arena, highlighting that current voluntary normative regimes-such as the UN Principles of Responsible Investment—seem insufficient (Richardson 2009). Besides the classical approaches of positive and negative screening, mixed strategies - such as the two-stage approach, which starts with negative screening followed by positive criteria, and the trade-off approach, which calculates an overall score or rating for companies-are discussed (Cowton 1999).

2.4.1.2 Best-in-class approach In addition to positive and negative screening, the best-in-class approach is often discussed in the literature and in practice. It holds that only those companies are considered for investment that, within their industry, are among those who act most socially and/or ecologically responsible. No industry is excluded at the outset (Cengiz et al. 2010). The idea behind this approach is that the better companies act as a model for the less-than-good companies (Bischofskonferenz 2010). A portfolio structured like this might be described as good, but not clean (Cowton 1999).

\subsubsection{Shareholder activism}

The term shareholder activism, also referred to as the activist approach, means that investors use their proxy votes to support the ethical development of companies (Camey 1994). It supports the idea that shareholders can use their specific rights and privileges as a tool for social change (Sandberg 2008:223). Solomon et al. (2002) provide an overview of issues and developments in the UK SRI market. They point out that shareholders, as company owners, can effect great changes through voting rights and personal meetings. Rivoli (2003) shows in her study that the voting of SRI shareholder proxies have had an effect in the past. Although all examined shareholder resolutions have failed to gather a majority for their case, nearly onethird of them were withdrawn owing to successful agreements between shareholders and management. Therefore, a positive impact of proxy voting can be assumed. For a practical example of proxy voting, see the USA Campaign at GM (Cowton 1998). For challenges by means of the activist approach, see Cullis et al. (1992).

\subsubsection{Community development investing}

Community development investing means that investors might give up some income to provide people with capital who would otherwise have no access to it 
through conventional channels (Schueth 2003). This can be done through charitable contributions, involvement in public-private partnerships, or volunteer programs (Lydenberg and Kurtz 1992:209). Sparkes (2001) argues that community development investing should not be seen as a part of SRI, but rather as socially directed investments (SDI). He notes that: "The essence of SDI is that SDI savers deliberately accept below market returns in order to help others; this is certainly not the intention of SRI.' This opinion is not shared by Bugg-Levine and Emerson (2011:5 et seq.) who argue that the separation between financial return and contribution to charities leads to a "waste of capital and talent". They promote the idea of impact investing, whereby positive impact on social and environmental challenges is executed while optimizing financial returns. Impact investing is becoming more and more important in the investment practice, as shown by Saltuk (2011). In her survey, she interviews high net worth investors, and finds that they want to allocate more funds to impact investing, expecting a total of 5-10\% of their portfolios being invested accordingly in 10 years' time. One possible application of impact investing is micro-finance funds. These funds help to direct investments into growing economies that do not yet have sufficient access to capital markets. Dorfleitner et al. (2011) distinguish between two different investment approaches in the micro-financing field: direct investments via debt and equity investments in micro-finance investments and indirect investments through specific micro-finance investment funds. Despite its practical relevance, community development and impact investing have not seen a wide coverage in academic literature and remain a field of further research.

Renneboog et al. (2008) consider negative screening to be the first generation of SRI screens, and positive screening as the second generation. The third generation of SRI screens combines positive and negative screenings, while the fourth generation combines the third generation with the activist approach. Hummels and Timmer (2004) identify an obstacle to implementing all these approaches. They point out that, in some case studies, sufficient information to determine whether a company matches investors' ethical requirements might be difficult to obtain. In short, they note that the "current reporting often misses this point and is not adequate and sufficient for investors to use in their investment process."

\section{Does SRI pay?}

\subsection{Development in academic literature}

Capelle-Blancard and Monjon (2012) confirm in their research a positive trend for academic articles on SRI between 1982 and 2009, with as many as 100 articles published on this topic in the later years. They display in their paper the major trends in literature on SRI, by using a simple content analysis on relevant phrases. They find, that in 2009 nearly two-thirds of all published academic articles cover performance measurement, which they explain by the fact that this research area is very data driven, as well as by the availability of respective data sets. Furthermore, they confirm new trends in SRI articles, besides performance measurement. The 
phrases stakeholder, corporate governance, sustainable, activism, and human rights have seen extensive growth in coverage over the researched time period. We follow this perception with our literature review and dedicate a large part of the following section to an overview on performance measurement.

\subsection{Performance of SR investments}

When it comes to measuring performance of SR investments over conventional funds, there seems to be disagreement in academic literature whether SRI is profitable or not. An extensive set of meta-studies on the relationship between financial performance and SRI exists. Mill (2006) names Wood and Jones (1995) who reviewed 60 empirical studies between 1970 and 1994; Pava and Krausz (1996) who looked at 21 studies between 1972 and 1992; Margolis and Walsh (2003) who researched on 127 studies between 1972 and 2002; Orlitzky et al. (2003) who analyzed 52 studies between 1972 and 1997; finally Salzmann et al. (2005), who researched on 15 studies between 1975 and 2001. In addition to this, Hoepner and McMillan (2009) reviewed 51 studies between 1991 and 2007. From these metastudies, Mill (2006) concludes a positive impact of SRI on financial performance. However, this result might be described as illusory, because a compilation of findings cannot produce a definite conclusion given the limitations of the underlying studies (Barnett and Salomon 2006). We therefore see a need to analyze the link between social and financial performance, by looking at individual studies. We took the meta-studies mentioned above as a first basis and enhanced them by studies published more recently. We further focus only on empirical studies based on market data for our analysis, and not studies based on accounting data or those that present a theoretical model approach. Overall, we examine 53 different empirical studies regarding SRI; of these, 35 use a performance analysis of ethical investment vehicles compared to conventional benchmarks and are therefore qualified to provide an answer to the question if SRI pays for investors. We also examine 18 studies that established relationships between a specific behavior perceived as ethical or unethical by most people and a single company's financial performance, to show whether SR behavior pays for the company. When conducting our set of studies, we focus mainly on studies of the past 15 years to display the latest trends in empirical analysis. To provide a complete picture of the empirical landscape, we add eight studies published more than 15 years ago. Our review covers a period of 27 years between 1986 and 2012 .

From a technical perspective, most studies-49 out of 53-perform regression analysis; of these, 27 provide an explanatory contribution on different factors that influence returns, besides ethical commitment. Here, one-, theee-, or four-factor models are used, such as CAPM, Fama-French, and Carhart. The CAPM considers market beta as an explanatory factor for asset price movements and is used in eight of the analyzed studies. For a detailed derivation on the CAPM, see Copeland et al. (2003:147 et seq.). Fama and French (1995) extend the CAPM by two additional factors, considering beta, size, and book-to-market values, but their approach is only used in two studies, although the size effect is cited by many as an explanatory factor. The Carhart model is based on Fama and French (1995), but with a fourth 


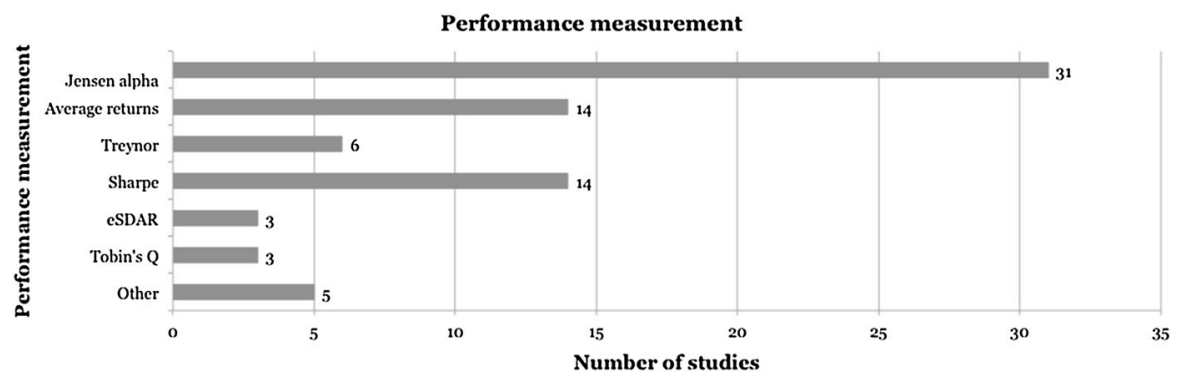

Fig. 2 Performance measures used in the 53 analyzed studies (multiple usages possible)

factor. This factor captures the Jegadeesh and Titman momentum anomaly, i.e., the return difference of past 12 months' winners and past 12 months' losers (Carhart 1997; Jegadeesh and Titman 1993). Eight studies use the Carhart model, 15 studies define their own factor models, and 26 do not use a factor model at all to determine different influence factors in their retrieved returns. Five studies use a matched pair approach in addition to a simple regression analysis. Thereby, SRI and non-SRI funds of similar characteristics are compared, to reduce effects in size or investment style when comparing returns. Here, important studies are: Mallin et al. (1995); Gregory et al. (1997); Statman (2000); Kreander et al. (2005). Five studies use other methods such as implementing trading strategies (Gompers et al. 2003) or event studies that focus on only one point in time.

Besides different comparison methods, the analyzed studies also differ in the choice of performance measures and benchmarks they use. Both factors are very significant when determining the performance of SRI vehicles and their conventional counterparts. It must be noted that many studies use more than one performance measure; Fig. 2 provides an overview of the measures that are used. Besides average portfolio returns, which are used in 14 studies, the following performance measures are used.

The Jensen alpha (Jensen 1967) is used in 31 of the analyzed studies. The Treynor ratio (Treynor 1965) is used six times, and the Sharpe ratio (Sharpe 1966), is used in 14 studies. The excess standard deviation adjusted return (eSDAR), as calculated by Statman (2000), quantifies the extra return at a specific point in time that could be earned by a portfolio when using the same amount of risk as the specified benchmark (Cengiz et al. 2010). The measure is used in three studies. Finally, Tobin's Q (Tobin 1969) is also used in three studies.

In addition to the choice of performance measure, one of the primary goals of performance measurement is to find an appropriate benchmark to compare one's portfolio to (Henningsen 1992). In their paper Fowler and Hope (2007) provide an overview of the major sustainability indices, which screening methods they use and which benchmark index underlies them. The best-known indices are introduced in detail by Sparkes (2002:295). He discusses the US-based Domini Social Index by KLD and the Dow Jones Sustainability Index, as well as the UK-based FTSE4Good index. The Domini 400 social index (sometimes also referred to as the KLD 400 index, because it was established by Kinder, Lydenberg, Domini and Company) is 
Fig. 3 Smaller sample size in performance studies

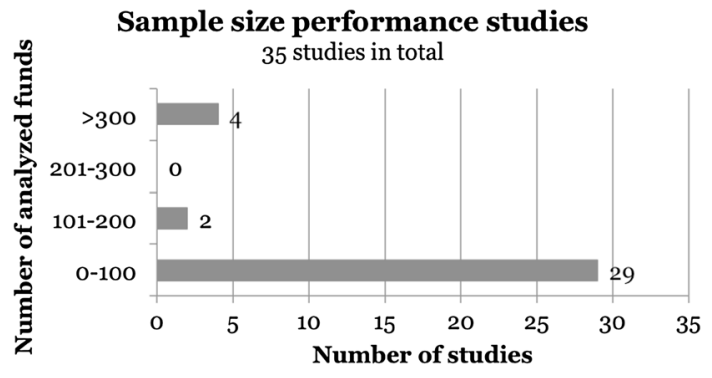

one of the best-known indices regarding social topics. Launched in March 1990, it is referred to as the "first broad market, common stock index in the United States designed to measure the performance of portfolios subject to multiple social constraints" (Kurtz et al. 1992). When launched, it applied primary screens on military contracting, alcohol and tobacco, gambling, nuclear power, and South Africa, as well as secondary screens on corporate responses to environment, product quality, and attitudes toward consumers, corporate citizenship, employee relations, women, and minorities. In a first step, the screen is applied to the S\&P 500, which delivers 257 remaining companies that are included in the index. Furthermore, 40 smaller companies with strong social positives are added to the index and, finally, 100 large capitalization stocks in underrepresented industries that surpass all screens (Kurtz et al. 1992). In the studies, we analyze a very broad range of different indices used as benchmarks.

However, indices have more uses beyond benchmarking. Already, a few studies have compared the performance of SRI indices to conventional indices: Sauer (1997), DiBartolomeo and Kurtz (1999), Statman (2000), and Schröder (2004). As Sauer (1997) points out, the advantage of using indices is that transaction costs, management fees, and differences in investment policy can be eliminated so as to isolate any potential performance implications more clearly.

The studies we analyze can further be distinguished according to sample sizes. Here, one should distinguish between performance studies, which focus on a mostly smaller number of mutual funds or indices and those that establish relationships with single companies to prove a relationship between social behavior and company performance, because these studies usually work with a larger sample size. The average performance study sample size is 125 samples (see Fig. 3). The average relationship study sample size is 198 (see Fig. 4).

When asked on his view on SRI, the 1976 Nobel Prize winner, Prof. Milton Friedman, said: "If people want to invest that way that's their business. In most cases such investing is neither harmful nor helpful" (Laufer 2003). Numerous studies have been performed solely to determine how SR investments perform compared to conventional investments. While Henningsen (1992) provides a basic introduction to how performance should be measured in a social portfolio, there is as yet no agreement in the academic literature as to how this relationship can be described (Camey 1994; Cowton 1998). Hamilton et al. (1993) formulate three different hypotheses on the relationship between SR investment returns and conventional investment vehicle returns. Ethical funds or indices can outperform, 
Fig. 4 Larger sample size in relationship studies
Sample size relationship studies

18 studies in total

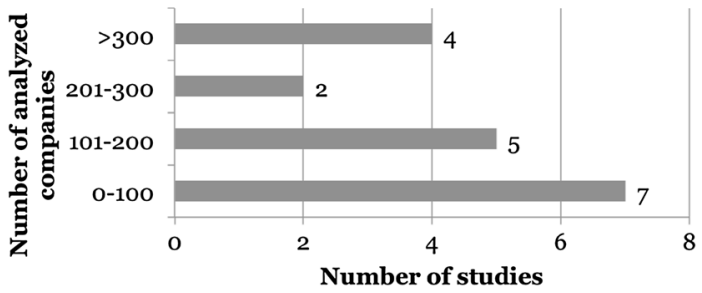

underperform, or perform as well as conventional funds or indices. As Fig. 5 shows, of the 35 studies that compare SRI vehicle performance to conventional benchmarks, 15 conclude that SRI vehicles perform in the same way as their conventional benchmarks, 6 find underperformance, and 14 exhibit outperformance compared to their various benchmarks. We performed a simple sign test on these results, finding that the fraction of studies that find outperformance of SR investments over their conventional counterparties is significantly larger, at a $10 \%$ level, than the portion finding underperformance. The main studies that provide proof of the three relationships are presented below.

\subsubsection{SR = conventional portfolio returns}

Hamilton et al. (1993) find this first hypothesis consistent with a world in which social responsibility is not priced in the market, i.e., SR investors who want to sell their shares find enough conventional buyers for them, so share pricing is not affected. As Guerard (1997b) phrases it, being a socially conscious investors is at least not "dumb". This also means that SR companies do not acquire any benefit by acting accordingly, because their cost of capital is not reduced, compared to conventional companies. Within their study, Hamilton et al. (1993) confirm this hypothesis by analyzing the Jensen alpha of 32 SRI mutual funds compared to value-weighted NYSE returns. The following papers provide empirical evidence for the hypothesis that SR investment returns are equal to the returns of conventional portfolios: Guerard (1997a) shows that no significant outperformance can be achieved by means of ethical screening. Sauer (1997) compares a well-diversified SRI portfolio - the Domini Social Index 400 - with two benchmark portfolios. His studies find that the SRI portfolio does not underperform the benchmark portfolios; this is confirmed by the use of different performance measures: the Jensen alpha, the Sharpe ratio, and average monthly raw returns and variability. In their study, Teoh et al. (1999) analyze companies divesting from South Africa between 1986 and 1989 and did not find significant different relative performance compared to their benchmark portfolio. For the Australian market, Cummings (2000) compares seven local ethical mutual funds, without finding significant over- or underperformance of those compared to their local benchmark indices. Statman (2000) compares the Domini Social Index between 1990 and 1998 with the S\&P500, and also finds no underperformance. When comparing SR mutual funds, he finds that they 
Fig. 5 Performance results

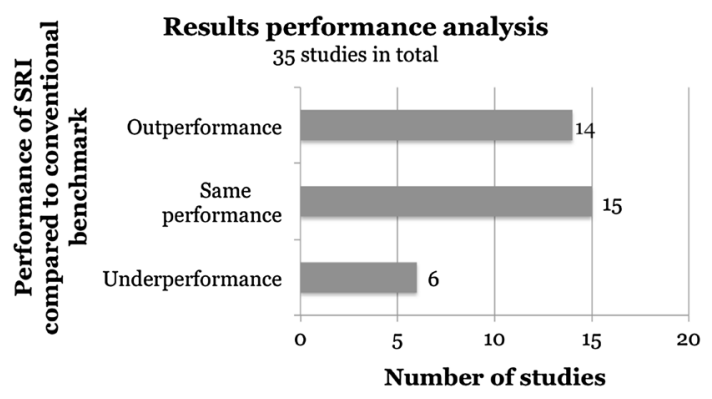

underperform both indices, but are not worse than conventional mutual funds. In his paper, Schröder (2004) compares US, German, and Swiss SRI funds and also finds no significant underperformance compared to their specific benchmarks. He finds that US investors are overinvested in blue chip stocks, whereas German and Swiss SRI funds invest more in smaller stocks. Bello (2005) uses a matching approach, and shows that between 1994 and 2001 ethical funds did not underperform or outperform conventional funds regarding the effect of assets held, portfolio diversification, and variable effects of diversification on investment performance. The compared portfolios both stay well behind their benchmarks (S\&P500 and the Domini 400 Social Index). He uses Morningstar data to determine 42 SR mutual funds (including 3 dead funds) to heal survivorship bias, and matches those with two randomly selected conventional funds of approximately the same net asset size. He uses three different measures to define portfolio performance: Jensen alpha, Sharpe information ratio, and eSDAR. Bauer et al. (2005) researched German, UK, and US ethical mutual funds and find no evidence of significant differences in risk-adjusted returns between ethical and conventional funds between 1990 and 2001. They use the CAPM and Carhart's four-factor asset pricing model for return calculations. They find that distinct investment styles are used-ethical funds seem to be less exposed to market variability than conventional funds. They also find a catch-up period regarding returns since 1990, possibly due to learning effects, but only average returns between 1998 and 2001. They extend their study to the Australian market using the same methods. They investigate the performance of 25 ethical mutual funds compared to the Worldscope Australian Index, showing equal performance for the period between 1996 and 2003, after a catch-up period between 1992 and 1996 (Bauer et al. 2006); a further analysis performed on the Canadian market comes up with the same results (Bauer et al. 2007). Kreander et al. (2005) study 60 European funds 30 ethical, and 30 non-ethical over the period 1995-2001 using a matched pair analysis, and find no signs of significant outperformance of the ethical funds over the non-ethical funds. They match the funds on the basis of age, size, and investment universe. Their study might contain survivorship bias, but since non-ethical funds and ethical funds should be affected in the same way, this was not seen as problematic. They use log returns to reduce the effect of skewness in the return distribution. Mill (2006) also finds no difference in performance between SRI and conventional funds. What is exceptional in his study is that he compares data for only one fund that has switched its investment style from conventional to SRI. 
Although he finds no significant underperformance or outperformance, the fund's variance has been higher for 4 years after the style switch, which might be due to portfolio manager learning effects. Amenc and Le Sourd (2008), focusing on France, look at 2002-2007 and cannot find any outperformance by ethical indices and ethical mutual funds over their conventional alternatives. Researching European ethical fund portfolios between 1991 and 2009, Cengiz et al. (2010) find that, due to title selection restrictions, a worsening of the risk-return profile occurs. Their fund portfolios are split into three clusters: principle-oriented (negative screening approach combined with positive criteria), best-in-class approach and ecologyclimate-environment. They conclude that none of their analyzed clusters could beat the benchmark. Only the principle-oriented cluster is little behind its benchmark, while the other two clusters fall well behind. Besides the Hamilton et al. (1993) argument that SRI is simply not priced in the market, another reason why the performance of social and conventional funds is closely correlated might be that the specific holdings in the two different portfolios do not differ from their conventional counterparts as much as expected. Haigh and Hazelton (2004), for example, find that Australian SRI funds are invested in 171 of the 200 largest companies. Table 1 summarizes the discussed studies.

\subsubsection{SR $<$ conventional portfolio returns}

The second hypothesis by Hamilton et al. (1993) expects SRI portfolios to deliver smaller returns than conventional portfolios. This is supported by Rudd (1981), who argues along the lines of classical portfolio theory. Because social responsible criteria limit fund managers' allocation possibilities, they lead to additional costs and investment risk, negatively impacting the portfolio's performance. The possibility of uncompensated risk in a socially screened portfolio is also mentioned by Kurtz (1997); it is perceived to be one of the largest obstacles to SRI implementation. This argument is supported by Luther et al. (1992), who hold that SRI portfolios' returns might be smaller, due to additional monitoring costs, a restricted investment portfolio, and fewer diversification possibilities. Cowton (1998) argues that it seems likely that SRI fund returns are smaller than those of the various mainstream funds, because mainstream investors could build the same portfolio as SR investors, but not vice versa. Michelson et al. (2004) as well as Tippet (2001) refer to the lower returns of SRI funds as an "ethical penalty." Although the reasoning above is consistent with classical portfolio theory, only six studies find empirical support for the hypothesis for lower than expected returns of SRI portfolios compared to conventional funds. Mueller (1991) tests ten mutual funds with ethical restrictions and finds significant underperformance compared to conventional funds in this category. An investor loses on average approximately $1 \%$ point of return per year by incorporating ethical considerations when making investments. In his study, Teper (1992:343 et seq.) compares the KLD 400 between 1985 and 1989 with the S\&P 500 and finds significant underperformance of the SRI approach. Furthermore he compares a South Africa-free portfolio, a sin-free portfolio (without alcohol, tobacco and gambling stocks), a portfolio without major defense contractors, and a portfolio that eliminates birth control manufacturers. For 


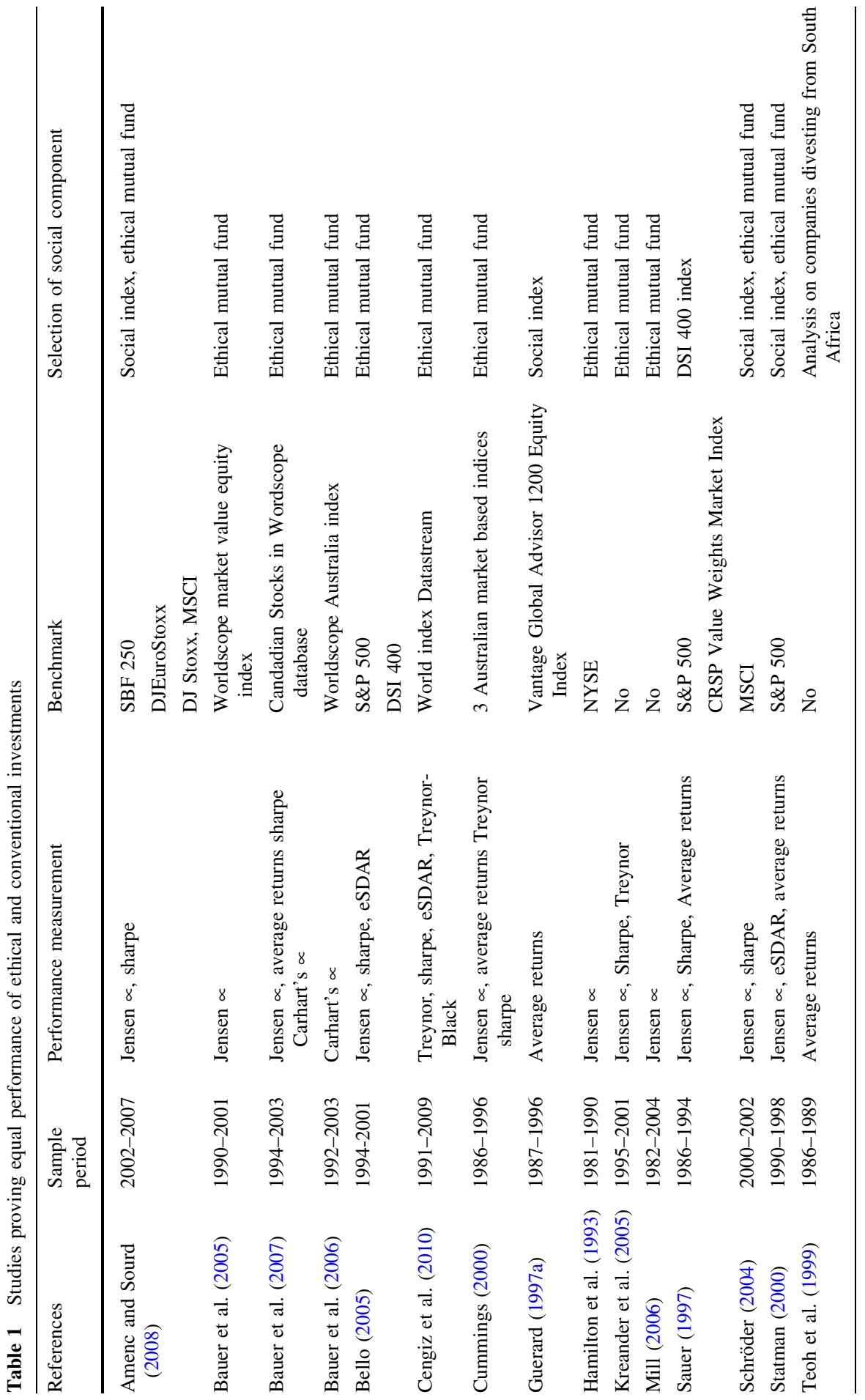


all portfolios except the major defense contractors, he finds underperformance of the SR investment compared to the S\&P 500 between 1979 and 1989. Gregory et al. (1997) conduct a matched pair and a cross-sectional analysis, and concerning both find a tendency to underperform in ethical funds compared to their benchmarks. Kahn et al. (1997) compare the performance of a tobacco-free S\&P 500 portfolio with the complete S\&P 500 portfolio and find underperformance for the tobaccofree portfolio between 1986 and 1996. In his study, Tippet (2001) shows significant underperformance of the three major Australian ethical mutual funds between 1991 and 1998 compared to their benchmarks. He holds higher transaction costs and management fees responsible for this underperformance. Finally, Geczy et al. (2005) connect the costs of SRI with the investment views of different investors: while investors following a market index realize only a view basis points of underperformance per month, investors looking closer at fund manager skills have much larger costs of up to 30 basis points per month. The six relevant studies in this section are summarized in Table 2.

\subsubsection{SR > conventional portfolio returns}

The reasoning behind the third hypothesis by Hamilton et al. (1993) that SRI firms' returns are higher than those of their conventional counterparts is that investors might underestimate the impact that negative news due to irresponsible behavior might have on conventional fund performance. Such negative news would lead to conventional portfolio underperformances, and, vice versa, to SRI portfolio outperformance. This argument is supported by Moskowitz (1972), who finds that good environmental screening does decrease the likelihood of high costs owing to environmental disasters that would decrease conventional portfolio returns. He finds that a good social and environmental performance is a signal of good managerial quality, which might lead to an increase in SRI portfolio returns. Further, he provides a first portfolio of 14 SR companies, but does not draw a conclusion regarding their performance. Finally, SRI mutual funds might yield higher returns because they are subject to more scrutiny_or at least should be-than conventional funds (Schwartz 2003).

The following papers find empirical evidence for higher-than-expected SRI portfolio returns: One of the initial motivations for SRI was the late apartheid regime in South Africa. This led to a global discussion of whether investments in companies doing business in or with South Africa should be excluded. Grossman and Sharpe (1986) examine the effect of divestments from South African companies to receive more ethical investment results. They find that portfolios without South Africa-related companies show superior returns, at the same level of risk, compared to conventional funds. Luther et al. (1992) investigate UK ethical unit trusts and find weak evidence of outperformance of ethical funds over their conventional counterparts on a risk-adjusted basis. However, they consider their results as limited on the basis of being too varied, as well as too closely correlated with low yields to allow for any relation between returns and ethical effects in SRI portfolios. They also find a small company bias and low dividend yields for their screened portfolios. The reason for the small company bias might be that it is very likely to 
Table 2 Studies proving underperformance of ethical over conventional investments

\begin{tabular}{|c|c|c|c|c|}
\hline Study & $\begin{array}{l}\text { Sample } \\
\text { period }\end{array}$ & $\begin{array}{l}\text { Performance } \\
\text { measurement }\end{array}$ & Benchmark & $\begin{array}{l}\text { Selection of social } \\
\text { component }\end{array}$ \\
\hline $\begin{array}{l}\text { Geczy et al. } \\
\text { (2005) }\end{array}$ & 1999-2001 & Sharpe & $\begin{array}{l}\text { Customized } \\
\text { benchmark }\end{array}$ & Ethical mutual funds \\
\hline $\begin{array}{l}\text { Gregory et al. } \\
\text { (1997) }\end{array}$ & 1986-1994 & Jensen $\propto$ & HGSCI, FTASI & Ethical mutual funds \\
\hline $\begin{array}{l}\text { Kahn et al. } \\
\text { (1997) }\end{array}$ & 1987-1996 & Total return & S\&P 500 & $\begin{array}{l}\text { Tobacco companies excluded } \\
\text { from S\&P } 500\end{array}$ \\
\hline $\begin{array}{l}\text { Mueller } \\
\text { (1991) }\end{array}$ & 1984-1988 & $\begin{array}{r}\text { Jensen } \propto, \\
\text { Treynor }\end{array}$ & Vanguard index 500 & Ethical mutual funds \\
\hline Tippet (2001) & 1991-1998 & $\begin{array}{r}\text { Jensen } \propto, \\
\text { Treynor }\end{array}$ & $\begin{array}{l}\text { All ordinaries } \\
\text { accumulation index }\end{array}$ & Ethical mutual funds \\
\hline Teper (1992) & 1979-1989 & Total return & S\&P 500 & $\begin{array}{l}\text { Ethical mutual funds, KLD } \\
400 \text { index }\end{array}$ \\
\hline
\end{tabular}

find at least one department in a very large diversified company that might be considered unethical, whereas small companies are much less likely to be allocated to the "unethical" section. In their study covering the years 1986-1993, Mallin et al. (1995) find weak signs of outperformance when comparing ethical funds to nonethical funds. They find that ethical trust funds outperform non-ethical trust funds, but both perform worse than the market. The study by D'Antonio et al. (1997) identifies 140 SR companies out of the KLD 400 index, and compares their bond performance with the general Lehman Brothers Corporate Bond Index (LCB); they find that the SRI bonds outperform their benchmark, but they credit this result to the differences in credit risk of the investigated portfolio and its LCB benchmark. In 2000, they reevaluated their previous study, looking at differences in allocation strategies and compared mixed equity and debt SRI portfolios with their conservative benchmarks. They look at different investment strategies-such as the buy and hold approach, constant mix, and constant proportion-and find significant outperformance on a strict return basis for all strategies. Considering risk, most analyzed portfolios outperformed their benchmarks, but portfolios with more than $70 \%$ allocated to equity underperformed (D'Antonio et al. 2000). In his study, Travers (1997) focuses on SRI outside the USA. He finds outperformance when comparing 23 selected SRI mutual funds from Europe, Australasia, and Asia with their benchmark, the MSCI EAFA Index (Morgan Stanley Capital International Europe, Australasia and Far East Index). One drawback of this study is the relatively short time frame. DiBartolomeo and Kurtz (1999) show outperformance of the Domini Social Index 400 over the S\&P 500 between 1990 and 1999, but find that this outperformance is not generated by some "social factor" but is merely due to macroeconomic effects, the DSI 400's high exposure to growth-oriented stocks, as well as industry-specific risks. Epstein and Schnietz (2002) divide the Fortune 500 index into three separate groups-environmentally abusive firms, labor-abusive firms and the rest - and look at a specific point in time: the failure of the 1999 WTO talks. They find that, around this event, the first two groups performed significantly poorer than the remaining portfolio. For 1997-2001, Bragdon and Karash (2002) 
also find outperformance when comparing their self-generated social index with the MSCI World Index as well as the S\&P 500 Index. In a study of 1995-2003, Derwall et al. (2005) specifically examine non-environmentally friendly and environmentally friendly stock portfolios and find significant outperformance by the environmentally friendly portfolio. Furthermore, Gompers et al. (2003) show a positive effect of strong corporate governance on company performance. In their study, they set up a governance index, ranking 1,500 firms according to their shareholder rights. They then implement a trading strategy, selling the firms with lowest shareholder rights and buying those with most shareholder rights. With this simple strategy, they earn an abnormally high return of $8.5 \%$ per year. These findings correspond well with the explanation by Tippet (2001) that excluding firms where management behavior is considered unethical should lead to significant outperformance, because firms with unnecessary costs are avoided. Shank et al. (2005) compare 11 firms that are well known for their SR behavior with selected SRI mutual funds and a conventional benchmark. They find that-for the short-term, 3- and 5-year time horizons-neither the selected single firms nor the SRI mutual funds are able to outperform the market. However, in terms of long-term (10-year) performance, the 11 selected firms produce significant positive alpha, thereby outperforming the market. In their study, Hill et al. (2007) researched on SR firms in Europe, Asia, and the USA. They identify a set of SR companies and compare their returns to their conventional benchmarks (S\&P 500 for the US, Nikkei 225 for Asia, and FTSE 300 for Europe). They conclude that the examined European companies outperformed their benchmark in the short term, whereas Asian and US companies did not perform significantly differently to their benchmarks. An explanation of this might be differences in national culture's influence on SRI. Kempf and Osthoff (2007) implement a simple trading strategy: buy stocks with a high SR investment rating, and sell those with a low rating. With this strategy, they achieved an abnormally high performance of up to $8.7 \%$ per year. Especially good results are obtained for application of the best-in-class approach, stocks with extreme social ratings, and a combination of several social screens at a time. The results also hold if high transaction costs are applied. All discussed studies are displayed in Table 3.

To summarize to date the relationship between social responsibility and returns has not been conclusive. Fowler and Hope (2007) conclude that "Despite the considerable research, there is no consensus in the academic or practitioner communities on the relative performance of SRI mutual funds." A possible explanation for the different results discussed above is provided by Barnett and Salomon (2006), who put forward a possible solution on why the debate on the relationship between SRI and financial performance has gone on for so long. They find that one must decide either to wholeheartedly follow an intensive SR investment screening process and gain extra returns as better managed and more stable firms are selected, or exclude very few firms to retain the ability to diversify. In their approach they do not-as many studies have done before-compare SRI and conventional funds, but address differences within SRI funds and look at different screening methods. They conclude that the relationship between financial and social performance is neither purely positive nor purely negative, but curvilinear, i.e., the best financial performance is at the lowest and highest social 


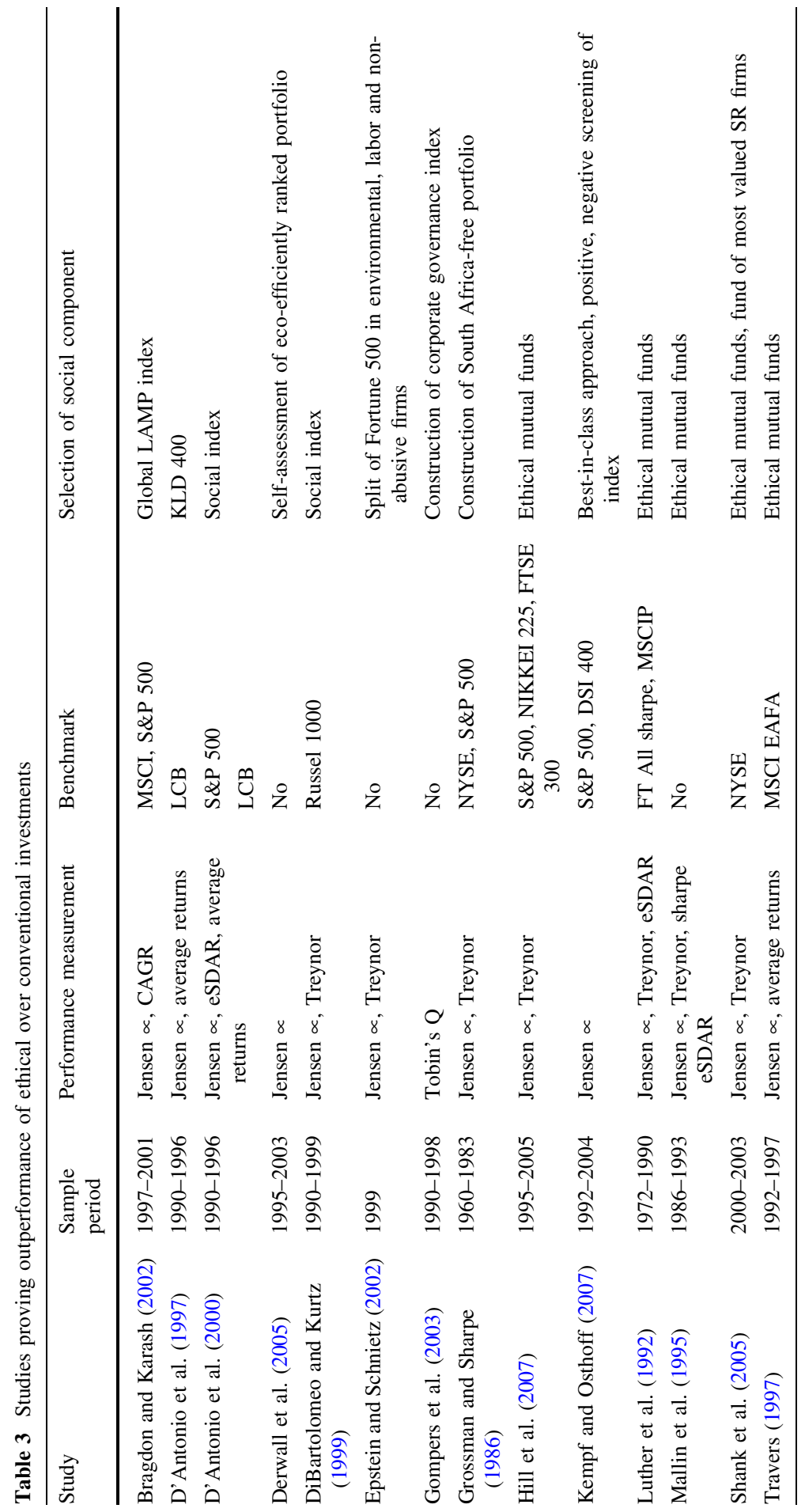


responsibility levels. But those funds with a maximum screening of 12 still underperformed by roughly $2.4 \%$ per year compared to those funds that performed only one screen. Therefore, it cannot be concluded that social screening does not come at a cost. The same reasoning has been used before by David Diltz (1995), who finds different performance results, depending on the type of screen he uses on a predefined portfolio. The influence of different screening methods is also held responsible by Tippet (2001), for the different findings in the academic literature regarding the relationship between ethical investments and financial returns: if the screening approach is based simply on a company's product (e.g., alcohol or tobacco), it is likely that profitable companies are excluded from the portfolios and that underperformance is reported. On the other hand, if the screening is based on management's ethical behavior (i.e., if independence of auditors or management remuneration are considered), excluding firms behaving unethically in this understanding will most likely exclude companies from the portfolios that bear additional costs and therefore most likely show outperformance compared to their conventional benchmarks. Another explanation for the different results produced by the various studies is that there are so many different definitions of SRI, which might affect the outcome of the research (Sandberg et al. 2009).

But it might be questioned whether SRI funds' performance is at all relevant for certain investors. In their study, Benson and Humphrey (2008) find that SRI fund flows are overall less sensitive to past returns than conventional fund flows and that SR investors are more likely to reinvest in funds they already own. The flowperformance relationship is asymmetric, i.e., the best-performing SRI funds receive the largest share of the inflow, but the poorest performing SRI funds do not experience the similarly large outflows. They conclude this is due to SRI fund investors' difficulty to find adequate ethical funds that match their non-financial goals. They have higher search costs to determine a fitting alternative fund. Furthermore, Bollen (2007) finds that cash inflows into SRI funds are more stable and independent from the fund's past performance, than regular mutual funds.

The assessment of the empirical studies above shows the heterogeneity of results when comparing the connection between social and financial performance. GarciaCastro et al. (2010) name three potential reasons for the contradictory results. First, they point out that social performance is difficult to assess, and sophisticated measures to do so are still not widely accepted. Further, they state that certain circumstances might influence the relationship between social and financial performance in a way that is not yet completely understood. Finally, the longand short-term analysis of the relationship between social and financial performance might account for the different results. In their article, they find support for a fourth argument. They show that endogenous effects influence this relationship, as a company's management makes its strategic decisions not randomly, but based on specific internal information not available to the broad market. Derwall et al. (2011) argue that the different investment styles of investors might be the reason for the variety of results. Regarding the perceived underperformance of SR investments, they argue with the "shunned-stock hypothesis", whereby value-driven investors use negative screening approaches to derive their investments, thereby screening out non-SR investments which leads to an overall decreasing demand in the market, 
resulting in relatively lower stock prices. On the contrary, they state that the profitdriven investors who use positive screening approaches can explain the outperformance of these investments. The "error-in-expectations theory" might be accountable for the perceived outperformance of SR investments, as the market continuously seems to undervalue the positive effects CSR might have on a company. Although both theories cannot hold true in the long run, the combination of both screening approaches in practice at the moment might be an explanation for those performance studies, finding similar performance for SR and conventional funds. As Fig. 2 shows, the vast majority of the analyzed performance studies use Jensen's alpha to determine the relative performance of the portfolio; Galema et al. (2008), however, argue that SRI lowers the book-to-market ratio and therefore alpha is not suited to capture the positive SRI effects. While confirming a positive relationship between financial and social performance, they also provide a possible explanation why many studies find different results when trying to establish a link between alpha and SRI.

\subsubsection{Comparison of single companies}

As noted, most studies construct SRI portfolios and compare them on a portfolio or index basis to their conventional counterpart. Another approach is to look at single company values to determine the effects of SR behavior, mostly referred to as CSR. A good overview of the status of CSR in Europe is provided by Habisch et al. (2005). They provide qualitative insight into CSR history as well as the status quo in 23 European countries. For an overview on the impact the financial crisis of 2008 had on CSR projects, see Jacob (2012). The major studies on CSR effects on single company values are shown in Table 4 . There are two ways to measure company value: by using accounting or market data. Most studies focus on market values, determined by company stock price times shares outstanding, since they want to determine CSR's effect on shareholder wealth (Mackey et al. 2007). Hill et al. (2007) find differences in European CSR-conscious companies' performance, compared to Asian and US ones. They conclude that there might be differences in the national culture between these countries and that European investors appear to value SRI higher than Asian and US investors. Mackey et al. (2007) conduct a theoretical study and find a positive correlation between firms participating in CSR and company value. However, this seems rather straightforward, since they use the basic assumption that managers will only take on those SR decisions that improve company value.

They present a supply and demand model, which does not provide consistent results on the relationship between CSR activities and company value. This model shows that if the demand for SR investment opportunities generated by respective investors is greater than the supply, then such investments could generate economic value for the company. Nevertheless, the model also suggests, that if supply and demand conditions are unfavorable, the company's market value might also be reduced by such measures. There are two different approaches to determine if SR firms have a higher value than conventional firms. It can be shown by event studies, for example, that stock prices rise when a company receives an environmental 


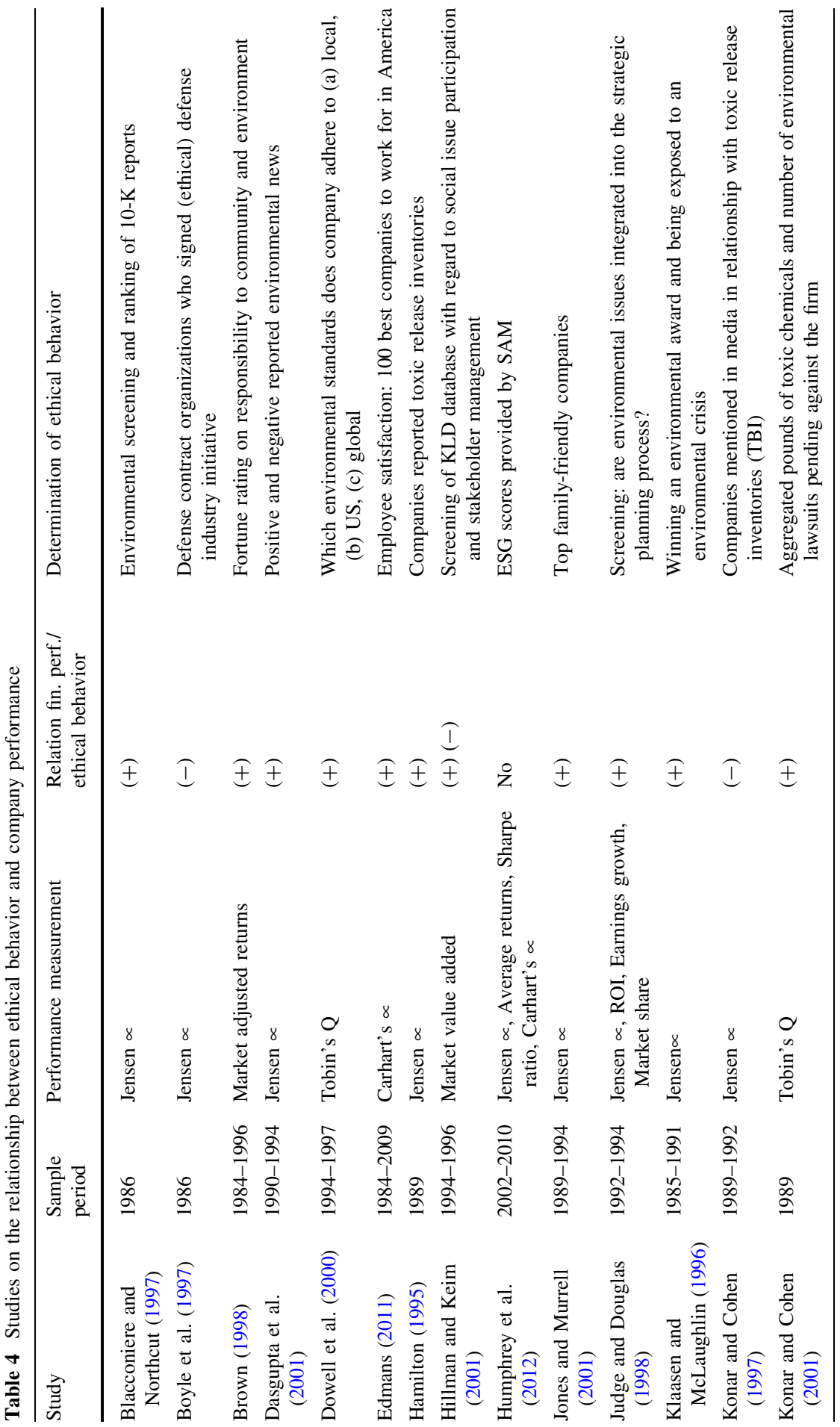




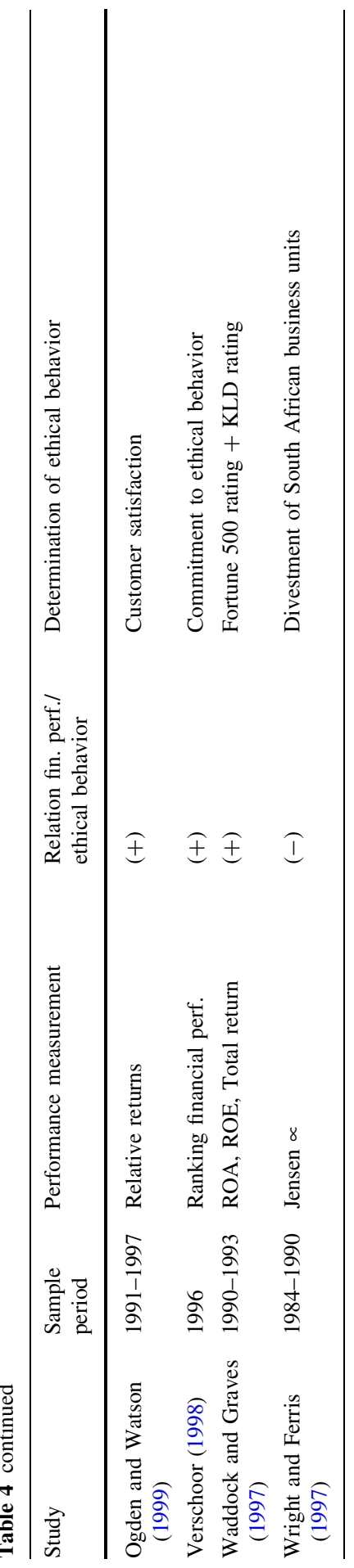


award (Klaasen and McLaughlin (1996); or vice versa, if information on toxic release, or an environmental crisis is published, the stock price drops significantly (see Hamilton (1995) and Klaasen and McLaughlin (1996)). Dasgupta et al. (2001) confirm these findings for developing countries. Already, the explicit commitment to ethical behavior can have a positive effect on a company's financial performance, as shown by Verschoor (1998). This finding is contradicted-at least for the defense sector-by Boyle et al. (1997), who report a negative relationship between a company's performance and its participation in the ethical Defense Industries Initiative. Many event studies do not study CSR as a whole, but focus on specific characteristics such as environment or stakeholders. Some studies show that higher environmental standards are associated with higher market value, measured by Tobin's Q [for example, Dowell et al. (2000) as well as Konar and Cohen (2001)]. A positive relationship is also shown between a company's financial performance and its level of integration of environmental issues into its strategic planning process (Judge and Douglas 1998), its Fortune rating on responsibility for community and environment (Brown 1998); there has even been a positive effect on the company value being determined if a company is not named in the context of Toxic Release Inventory (Konar and Cohen 1997). Blacconiere and Northcut (1997) also find a positive relationship between the level of environmental information provided by a company and its financial performance. Apart from environmental relationships, the effects between financial performance and the treatment of a company's different stakeholders (such as employees, managers, shareholders, customers, creditors, society, government, or suppliers) is also subject of several studies. In their study, Hillman and Keim (2001) show a positive relationship between a company's market value added and its stakeholder management level, but find a negative relationship between market value added and social issue participation. Waddock and Graves (1997) look at this from another angle and confirm a positive relationship between a company's quality of stakeholder management and the quality of its social performance. Looking at customers as company stakeholders, Ogden and Watson (1999) prove that there is a positive relationship between customer satisfaction and financial performance, by analyzing the ten largest privatized water companies in the UK. Further, Jones and Murrell (2001) focus their research on a company's employee stakeholder group and prove a positive relationship between financial performance and whether or not a company is among the top family-friendly rated companies in the USA. This is supported by Edmans (2011), who shows a positive relationship between a company's financial returns and whether it is ranked under the 100 best companies to work for in the USA. Wright and Ferris (1997) find a negative relationship between divestments in South Africa between 1984 and 1990 due to the apartheid regime and companies' financial performance; they argue that the political pressure on the company managers was not well perceived by the capital markets. This negative relationship should be challenged, as Teoh et al. (1999) have conducted the same type of event study between 1986 and 1989 and find no negative or positive effect between divestiture announcements concerning South Africa and a company's financial performance. Finally, Humphrey et al. (2012) use SAM Rating data to describe the relationship of CSR behavior and financial costs. They do neither find a positive or negative relationship, confirming 


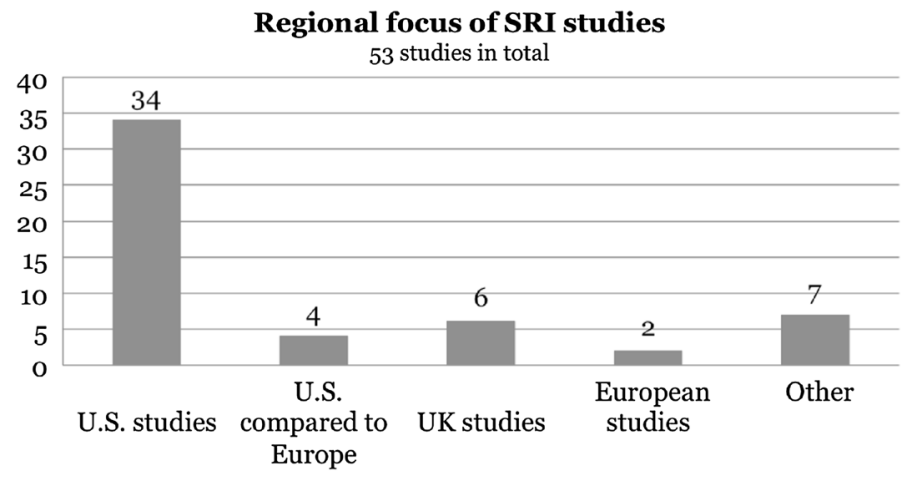

Fig. 6 US focus in research

that at least in the UK market, the implementation of CSR strategies should have no financial consequences for a company. To complete the picture, it has to be stated that CSR behavior does not only affect a company's cost of equity, as determined by the studies mentioned above. Goss and Roberts (2011) follow a different approach by determining the effect CSR consistent behavior has on the interest rates companies pay for their bank debt. They argue that the bank has a specific duty in monitoring a company's behavior before signing a loan agreement. They find that companies with a low perceived CSR behavior pay up to 18 basis points more for their loans than companies that are perceived to have a positive CSR behavior.

\subsubsection{Regional focus and time frame of SRI studies}

Besides categorizing the performance of our sample, we also analyze it with regard to the regional areas the studies cover to determine potential new research areas. The vast majority of studies focus only on the USA. Four studies compare the USA to selected European countries, six focus on the UK, and only two compare selected European countries (see Fig. 6).

When focusing on Europe, the UK is the primary country that is analyzed, which is due to the long history of SRI in the UK. Other studies compare European SRI vehicles in general without naming a specific country. As Fig. 7 shows, if Europe is considered in SRI studies at all, the vast majority researches the UK followed by other core European countries. Southern or Northern European countries are mostly neglected, and we find no studies on Eastern European countries (as displayed in Fig. 7).

Sandberg et al. (2009) state that cultural differences might be one explanation for heterogeneity in the field of SRI and that it is quite unlikely that these differences might be resolved in the near future. Most empirical studies discussed above focus on the US and the UK, as both countries have the longest SRI traditions as well as significant assets under investment. Recently, some studies have been published that compare different SRI aspects in different countries. (Maignan and Ralston 2002) compare the web sites of French, Dutch, UK, and US firms, and find that the Anglo countries tend to focus more on SRI topics then their French and Dutch 
Fig. 7 European countries researched

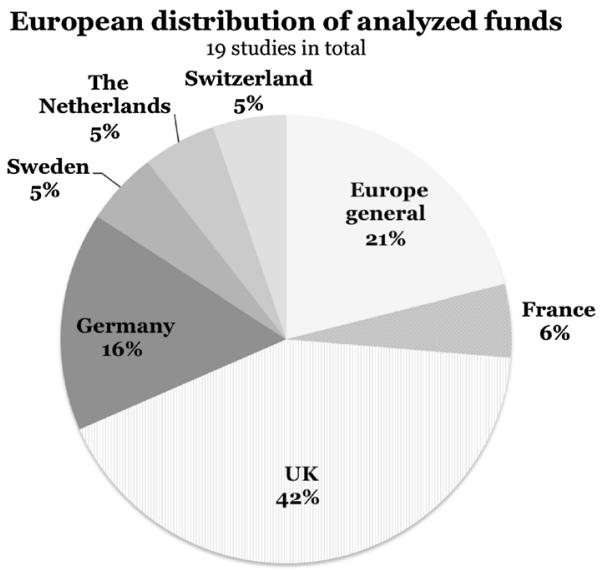

counterparts. One reason they provide for this might be the traditional responsible role of government in Europe regarding social issues, whereas in the Anglo countries, companies have had more autonomy regarding social issues. Bauer et al. (2005) find that in the USA, compared to the UK and Germany, different investment styles are used. While US ethical mutual funds are mainly invested in large caps compared to their conventional peers, UK and German ethical mutual funds are heavily exposed to small caps compared to conventional mutual funds. Schröder (2004) finds the same differences between US and German funds, but can also confirm that in Swiss SRI funds, like in German funds, small caps are overweighed. Chapple and Moon (2005) conduct a study of seven Asian countries (India, Indonesia, Malaysia, the Philippines, South Korea, Singapore, and Thailand) and find that social responsibility varies between these countries, which might be explained by national factors. They also confirm an enhancing effect of globalization on CSR in Asia. It is at least questionable, whether their study is representative as their main source of data are company website reports. Louche and Lydenberg (2006) compare SRI in the European Union and the USA and find that although the concepts are the same for both areas, the implementation differs. They conclude that SRI will become a mainstream investment pattern much quicker in Europe than in the USA owing to governmental influence and attention relating to SRI in the former. In the USA, proxy voting is mainly used to influence companies to act in greater accordance with SRI principles, which seems to be an active and more confrontational approach. Other differences include community development investing, a hot topic in the USA, but not yet relevant in Europe, as well as some differences in definitions. However, the main concepts and religious roots are the same for both regions.

Furthermore, we took a closer look at the timely distribution of the analyzed studies, as Fig. 8 outlines. We found that the vast majority of the performance studies were published between 1997 and 2005, which account for more than $65 \%$ of all analyzed studies, with a clear maximum of 11 studies in 1997. The declining number of performance studies from 2006 onwards points to a shift to new fields of research. This is in line with Capelle-Blancard and Monjon (2012) who, in their 


\section{Distribution of studies over time}

53 studies in total

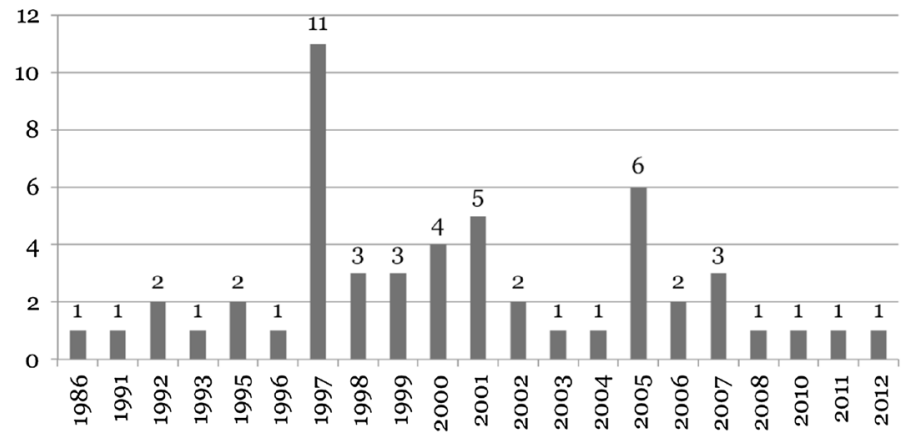

Fig. 8 Number of studies per publishing year

paper on trends in SRI literature point out that the topic of performance measurement has been somewhat overemphasized in the academic world. They also address the need for more conceptual and theoretical work in this research area.

\section{SR investment rating and new approaches for implementation}

It seems that this need for more conceptual and theoretical work has been picked up by scholars over the last years, as many of them have taken one step back from plain performance measurement. The latest publications show that before comparing SRI and conventional fund performance, a common understanding should be reached under which conditions a fund is considered SR. Therefore, it is necessary to develop a measurement to quantify how SR, a specific investment vehicle, really is. The second step would then be, to include this information into the portfolio selection, thereby deriving a SRI portfolio. The following section provides an overview on the coverage in academic articles of these two steps.

Ballestero et al. (2012) raise a question that has been neglected so far: how is an investment vehicle's social performance compared to its financial performance? One way to determine an answer to this is by introducing a rating approach, because as Dillenburg et al. (2003) correctly conclude, "what gets measured gets managed". They point out that a social metric system might have a substantial impact on how companies are steered in the future. A SR investment rating hereby can be defined as a systematic analysis of company information that are related to environmental, social, ethical, or cultural aspects (Pinner 2003:137). For a detailed overview on different rating agencies also see Pinner (2003:140 et seq.). In the context of SR investment rating, the terminology of ESG scores have lately been used more frequently in academic literature. It describes how SR a company acts with regard to environmental, social, and governance issues, and assigns a score to each of the individual topics. Finally, an average rating score is calculated out of each of the individual scores (Wimmer 2013). Dillenburg et al. (2003) introduce total social impact (TSI) rating, a holistic approach which considers the impact a company has 
on its seven stakeholders and assigns a rating score to each of them. The higher the score, the closer is the correlation between the companies' approach of handling the stakeholders and the best practice in this particular field. A variety of public and non-public data are collected for each of the seven groups to assess the individual rating scores. In addition, the category "trust and transparency" is rated, which is derived from information on the companies" "communication and transparency" toward their stakeholders and the general public. This category contributes $30 \%$ to the final TSI score-the remaining $70 \%$ are distributed equally among the stakeholder group scores. Koellner et al. (2005) also support the need for nonfinancial performance measures. They see, however, several obstacles in creating such a comprehensive rating. One major obstacle they see is that a sustainable asset is defined by values and preferences of the single investor, making a sustainable rating vulnerable to subjectivity in the rating process. Furthermore the strategic objectives of a group of sustainable funds might be very diverse making integration into a rating process difficult. Finally, certain information is crucial for a serious rating framework, but might not be accessible in practice. Generally speaking, there is a lack of sustainability reporting (Koellner et al. 2005).

Once a social rating approach is agreed upon, an interesting research question is whether SRI vehicles are really more SR than their conventional counterparts. Utz et al. (2014) use in their study the ESG scores from the rating agency Inrate. They compare 105 SRI funds with 82 conventional funds for the years 2009 and 2010 and find that the SRI funds have significantly higher ESG scores than the analyzed conventional funds. However, due to the high risk tolerance parameters they find for the conventional funds, in combination with similar investment returns between SRI and conventional funds, they conclude that ESG scores might be only "marginally important" objective parameters. This can be explained by an investment process where social screening is only the first step followed by financial optimization. Wimmer (2013) extends this discussion, by raising the question for how long they can keep their high ESG scores. In his study on the persistence of ESG scores of SRI vehicles, he finds that they maintain their high SR investment rating for the first 2 years, showing a significant decline after this time period. He further can prove that this decline is caused by the fund managers' allocation decisions and not by a decline in the company's ESG score per se.

The rating approach is a generalized method to determine how SR a mutual fund or a single company is. Social responsibility, however, means something different for every individual investor. While a rating can only approximate the unique utility function of an investor, new approaches look to implement the individual ethical investment demand of a single investor into portfolio optimization. As outlined by Mackenzie and Lewis (1999) and Lewis and Mackenzie (2000a), SR investors seem to prefer a mixture of SR investments and conventional funds. The optimal mixture can be determined by using multi-attribute portfolio optimization. This approach was first linked to SRI by Hallerbach et al. (2004). They use a "long list of social impact" from which a SR investor can choose from to determine his preferences. From this they use a multi-step optimization process to determine the optimal portfolio for this individual investor. Dupré et al. (2004) use rating data provided by the French rating agency ARESE, to determine the social component in their 
portfolio optimization approach. ARESE uses five different criteria to assign their rating: human resources, environment/health/safety, relations between customers and suppliers, relations between stakeholders, relations with the community. These are used to determine the amount of social responsibility a single investor wants to see in his portfolio. They can confirm that the costs for acting SR are considerably low as long as the "ethical appetite" is low, but the costs will grow accordingly as the investor puts more weight on the social component in his portfolio. Barracchini and Addessi (2012) introduce in their paper a model of portfolio selection that enhances the common risk-return profile by an ethical component, they characterize as "ethical coherence". It is defined by an ethical index that considers the personal ethical values of a single investor and adds it to the risk-return profile of its investment decision, resulting in an efficient frontier that gives this investor the opportunity to determine its optimal ethical portfolio, at a fixed level of risk. Ballestero et al. (2012) discuss in their paper an operational allocation approach that enables SR investors to select an appropriate portfolio consisting of ethical and unethical assets, according to their own needs. They test their allocation on a practical example and can confirm negative returns for very strict SRI portfolios, but could not prove the same for portfolios that only invest a small amount SR. Dorfleitner et al. (2012) also expand the classical portfolio theory with an additional social component. Social return is hereby measured by using micro-finance fund. This approach seeks to lay a theoretical basis to quantify social returns. Dorfleitner and Utz (2012) aim at a specific type of investor: the safety first investor that is concerned that his portfolio falls under a specified threshold with regard to return. In a first step, they determine the sustainability return for single investments by using sustainability ratings and further let the investor choose a combination of these objective values under consideration of his specific ethical utility function. They use the derived sustainable component and add financial returns as input factors into their model for safety-first portfolio selection. As displayed above, this field of research has gathered attention over the last years and a broad variety of different approaches are still under discussion. Further research might be necessary to determine a generally accepted integration of social responsibility into portfolio optimization.

\section{Future research}

For the future, we see the necessity to deepen efforts to determine SR investments' relative performance to conventional investment vehicles. We suggest focusing research in SRI on European countries. This could be brought into context with the European financial markets' current volatility. It would be interesting to determine what effect this has on ethical indices' performance. The ethical indices might have performed better than their conventional benchmarks, because they might have avoided companies investing in unethical vehicles, such as mortgage loan speculation. On the other hand, they might have performed worse, as periphery countries and home loans might have been perceived ethical before and European SRI mutual funds might have been more exposed than conventional investors. An 
empirical study should be conducted to determine the results. It should also be determined whether the indices' constituents have changed owing to the financial crisis, i.e., whether investors who were previously perceived as ethical fell out of the index due to unethical behavior during the financial crisis. As Fig. 6 shows, while already some empirical studies have covered SRI in Europe, mostly in comparison with the USA, the coverage of Europe has not been extensive. Existing studies on Europe mainly focus on the UK, because it has the longest history of SRI and the most developed market; these studies include a small number of other European countries, if any. An extensive study of SRI in Europe has not been conducted to date, and it would be interesting to discover the differences in SRI between European countries. To the best of our knowledge, there is no empirical study comparing German SRI mutual funds on a stand-alone basis.

Our paper has further shown that most empirical studies focus on SRI mutual fund portfolios, rather than indices. The hypothesis would be that, because index investing by means of exchange traded funds is becoming an increasingly important topic, the number of published SRI indices should have risen over the years, making this a topic worth investigating in detail. The above-mentioned studies point to future research areas, regarding the methodology behind the impact and construction of sustainable indices. Which steps must companies take to become licensed for a sustainable index and how do investors and the investment community respond to the rising number of licensed companies that are included in a SRI index?

Furthermore, the topic of social ratings is still an open research field. Although already a variety of rating agencies exist in practice, there is a need for more conceptual research performed on how social rating approaches can be implemented, which influence factors should be considered, and whether standardization of this process would be helpful, or if individualization is an integral part. This work should than be linked to the multi-factor portfolio optimization, defining a commonly accepted way to include social ratings into portfolio optimization, and applying the framework in practice. Finally, an explanation is missing why some of the current studies that have shown first models of multi-attribute portfolio optimization have determined negative returns, when investing larger amounts into SRI funds, while this effect could not be seen when investing smaller amounts.

\section{Conclusion}

In this paper, we have outlined the motives and increased interest that private and institutional investors have for combining ethical concerns and financial decisions. We have also shown different ways of fulfilling this demand by means of guiding portfolio investments, shareholder activism, or community development investing. We then analyzed a wide set of empirical studies and outlined the continuing discussions in the academic literature regarding the relative performance of SRI vehicles. In our meta-study, we find that the majority of research papers to date have found SRI funds to perform equally to conventional investments, a wide set has recognized outperformance of SR investments, and some studies even found a negative relationship between $\mathrm{SR}$ investments and conventional investments. 
Furthermore, we analyzed some studies that determined the relationship between a company's financial performance and its efforts to implement SR behavior in their company. These studies mainly point to a positive effect between SRI activities implemented by a company and its financial results. We concluded our paper with an overview on SR investment ratings and their integration into multi-attribute portfolio optimization.

Open Access This article is distributed under the terms of the Creative Commons Attribution License which permits any use, distribution, and reproduction in any medium, provided the original author(s) and the source are credited.

\section{References}

Aktas, N., E. de Bodt, and J.G. Cousin. 2011. Do financial markets care about SRI? Evidence from mergers and acquisitions. Journal of Banking and Finance 35(7): 1753-1761.

Allen, F., E. Carletti, and R. Marquez. 2007. Stakeholder capitalism, corporate governance and firm value, working paper, SSRN.

Amenc N., and V. Le Sourd. 2008. Socially responsible investment performance in France, working paper, SSRN.

Ballestero, E., M. Bravo, B. Pérez-Gladish, M. Arenas-Parra, and D. Plà-Santamaria. 2012. Socially responsible investment: a multicriteria approach to portfolio selection combining ethical and financial objectives. European Journal of Operational Research 216(2): 487-494.

Barnea, A., and A. Rubin. 2010. Corporate social responsibility as a conflict between shareholders. Journal of Business Ethics 97(1): 71-86.

Barnett, M.L., and R.M. Salomon. 2006. Beyond dichotomy: the curvilinear relationship between social responsibility and financial performance. Strategic Management Journal 27(12): 1101-1122.

Baron, D.P. 2001. Private Politics, Corporate social responsibility, and integrated strategy. Journal of Economics and Management Strategy 10(1): 7-45.

Barracchini, C., and M.E. Addessi. 2012. Ethical portfolio theory: a new course. Journal of Management and Sustainability 2(2): 35-42.

Bauer, R., J. Derwall, and R. Otten. 2007. The ethical mutual fund performance debate: new evidence from Canada. Journal of Business Ethics 70(2): 111-124.

Bauer, R., K. Koedijk, and R. Otten. 2005. International evidence on ethical mutual fund performance and investment style. Journal of Banking and Finance 29(7): 1751-1767.

Bauer, R., R. Otten, and A.T. Rad. 2006. Ethical investing in Australia: is there a financial penalty? Pacific-Basin Finance Journal 14(1): 33-48.

Bello, Z.Y. 2005. Socially responsible investing and portfolio diversification. The Journal of Financial Research 28(1): 41-57.

Benson, K.L., and J.E. Humphrey. 2008. Socially responsible investment funds: investor reaction to current and past return. Journal of Banking and Finance 32(9): 1850-1859.

Bischofskonferenz, Wissenschaftliche Arbeitsgruppe für weltkirchliche Aufgaben der Deutschen. 2010. Mit Geldanlagen die Welt verändern? Eine Orientierungshilfe zum ethikbezogenen Investment, Deutsche Bischofskonferenz. Bonn.

Blacconiere, W.G., and W.D. Northcut. 1997. Environmental information and market reactions to environmental legislation. Journal of Accounting, Auditing and Finance 12(2): 149-178.

Bollen, N.P. 2007. Mutual fund attributes and investor behavior. The Journal of Financial and Quantitative Analysis 42(3): 683-708.

Boyle, E.J., M.M. Higgins, and G.S. Rhee. 1997. Stock market reaction to ethical initiatives of defense contractors: theory and evidence. Critical Perspectives on Accounting 8(6): 541-561.

Bragdon, J., and R. Karash. 2002. Living-asset stewardship: how organizational learning leads to exceptional market returns. Reflections 4(1):55-64

Brekke, K.A., and K. Nyborg. 2004. Moral hazard and moral motivation: corporate social responsibility as labor market screening, working paper, SSRN.

Brown, B. 1998. Do stock market investors reward companies with reputations for social performance? Corporate Reputation Review 1(3): 271-280 
Bugg-Levine, A., and J. Emerson. 2011. Impact Investing: Transforming How We Make Money While Making a Difference. Jossey-Bass: San Francisco

Camey, B.F. 1994. Socially responsible investing. Health Progress 75: 20-23.

Capelle-Blancard, G., and S. Monjon. 2012. Trends in the literature on socially responsible investment: looking for the keys under the lamppost. Business Ethics: A European Review 21(3): 239-250.

Carhart, M.M. 1997. On persistence in mutual fund performance. The Journal of Finance 52(1): 57-82.

Cengiz, CBs, D. Braun, and R. von Nitzsch. 2010. Alpha-Vehikel oder Preis für das Gute Gewissen? Eine Performanceanalyse ethischer Investments, Corporate Finance biz 1(4): 263-271.

Chapple, W., and J. Moon. 2005. Corporate social responsibility (CSR) in Asia: a seven-country study of CSR web site reporting. Business Society 44(4): 415-441.

Copeland, T.E., F.J. Weston, and K. Shastri. 2003. Financial theory and corporate policy. Amsterdam: Pearson Addison Wesley.

Cowton, C.J. 1995. The development of ethical investment products. In Ethical conflicts in finance, ed. A.R. Prindl, and B. Prodhan, 213-232. Oxford: Blackwell.

Cowton, C.J. 1998. Socially Responsible investment. In Encyclopedia of applied ethics, ed. Ruth Chadwick, 181-190. San Diego: Academic Press.

Cowton, C.J. 1999. Accounting and financial ethics: from margin to mainstream? Business ethics: a european review 8(2): 99-107.

Cox, P., S. Brammer, and A. Millington. 2004. An empirical examination of institutional investor preferences for corporate social responsibility. Journal of Business Ethics 52(1): 27-43.

Cullis, J.G., A. Lewis, and A. Winnett. 1992. Paying to be Good? UK ethical investments, Kyklos 45(1): 3-24.

Cummings, L.S. 2000. The financial performance of ethical investment trusts: an Australian perspective. Journal of Business Ethics 25(1): 79-92.

D'Antonio, L., T. Johnsen, and B. Hutton. 2000. Socially responsible investing and asset allocation. The Journal of Investing 9(3): 65-72.

D’Antonio, L., T. Johnsen, and R. Bruce Hutton. 1997. Expanding socially screened portfolios: an attribution analysis of bond performance. The Journal of Investing 6(4): 79-86.

Dasgupta, S., B. Laplante, and N. Mamingi. 2001. Pollution and capital markets in developing countries. Journal of Environmental Economics and Management 42(3): 310-335.

Derwall, J., N. Guenster, R. Bauer, and K. Koedijk. 2005. The eco-efficiency premium puzzle. Financial Analyst Journal 61(2): 51-63.

Derwall, J., K. Koedijk, and J. Ter Horst. 2011. A tale of values-driven and profit-seeking social investors. Journal of Banking and Finance 35(8): 2137-2147.

DiBartolomeo D., and L. Kurtz. 1999. Managing risk exposures of socially screened portfolios. Northfield Information Services: 1-17.

Dillenburg, S.J., T. Greene, and H. Erekson. 2003. Approaching socially responsible investment with a comprehensive ratings scheme: total social impact. Journal of Business Ethics 43(3): 167-177.

David Diltz, J. 1995. The private cost of socially responsible investing. Applied Financial Economics 5(2): 69-77.

Domini, A.L. 1992. What is social investing? Who are social investors? In The social investment Almanac: a comprehensive guide to socially responsible investing, ed. P.D. Kinder, S.D. Lydenberg, and A.L. Domini, 5-7. New York: Henry Holt and Company.

Dorfleitner, G., M. Leidl, and C. Priberny. 2011. Microcredit as an asset class: structured microfinance. In Mobilising capital for emerging markets: what can structured finance contribute?, ed. Doris Köhn, 137-154. Berlin: Springer.

Dorfleitner, G., M. Leidl, and J. Reeder. 2012. Theory of social returns in portfolio choice with application to microfinance. Journal of Asset Management 13(6): 384-400.

Dorfleitner, G., and S. Utz. 2012. Safety first portfolio choice based on financial and sustainability returns. European Journal of Operational Research 221(1): 155-164.

Dowell, G., S. Hart, and B. Yeung. 2000. Do corporate global environmental standards create or destroy market value? Management Science 46(8): 1059-1074.

Dunfee, T.W. 2003. Social investing: mainstream or Backwater? Journal of Business Ethics 43(3): 247-252.

Dupré, D., I. Girerd-Potin, and R. Kassoua. 2004. Adding an ethical dimension to portfolio management. Finance India 18(April): 625-642.

Edmans, A. 2011. Does the stock market fully value intangibles? Employee satisfaction and equity prices. Journal of Financial Economics 101(3): 621-640. 
Epstein, M.J., and K.E. Schnietz. 2002. Measuring the cost of environmental and labor protests to globalization: an event study of the failed 1999 seattle WTO talks. The International Trade Journal 16(2): 129-160.

Eurosif. 2010. European SRI study. Paris: Eurosif.

Fama, E.F., and K.R. French. 1995. Size and book-to-market factors in earnings and returns. Journal of Financial Economics 33(1): 3-56.

Fisman, R., G. Heal, and V.B. Nair. 2006. A model of corporate philanthropy, working paper, SSRN.

Fombrun, C., and M. Shanley. 1990. What's in a name? Reputation building and corporate strategy. Academy of Management Journal 33(2): 233-258.

Fowler, S.J., and C. Hope. 2007. A critical review of sustainable business indices and their impact. Journal of Business Ethics 76(3): 243-252.

Friedman, A.L., and S. Miles. 2001. Socially responsible investment and corporate social and environmental reporting in the UK: an exploratory study. British Accounting Review 33(4): 523-548.

Friedman, M. 1970. The social responsibility of business is to increase its profits. The New York Times Magazine: SM17.

Galema, R., A. Plantinga, and B. Scholtens. 2008. The stocks at stake: return and risk in socially responsible investment. Journal of Banking and Finance 32(12): 2646-2654.

Garcia-Castro, R., M.A. Ariño, and M.A. Canela. 2010. Does social performance really lead to financial performance? Accounting for endogeneity. Journal of Business Ethics 92(1): 107-126.

Gasparino, C., and P.W. Tam. 1998. Feel-good mutual funds haven't yet found favor. Wall Street Journal: C1.

Geczy, C.C., R.F. Stambaugh, and D. Levin. 2005. Investing in socially responsible mutual funds, working paper, SSRN.

Gompers, P., J. Ishii, and A. Metrick. 2003. Corporate governance and equity prices. The Quarterly Journal of Economics 118(1): 107-155.

Goss, A., and G.S. Roberts. 2011. The impact of corporate social responsibility on the cost of bank loans. Journal of Banking and Finance 35(7): 1794-1810.

Gregory, A., John Matatko, and Robert G. Luther. 1997. Ethical unit trust financial performance: small company effects and fund size effects. Journal Of Business Finance and Accounting 24(5): $705-725$.

Grossman, B.R., and W.F. Sharpe. 1986. Financial implications of South African divestment. Financial Analyst Journal 42(4): 15-29.

Guerard, J.B. 1997a. Additional evidence on the cost of being socially responsible in investing. The Journal of Investing 6(4): 31-36.

Guerard Jr, J.B. 1997b. Is there a cost to being socially responsible in investing? The Journal of Investing 6(2): 11-18.

Habisch, A., J. Jonker, M. Wegner, and R. Schmidpeter. 2005. Corporate social responsibility across Europe. Heidelberg: Springer.

Haigh, M., and J. Hazelton. 2004. Financial markets: a tool for social responsibility? Journal of Business Ethics 52(1): 59-71.

Hallerbach, W., H. Ning, A. Soppe, and J. Spronk. 2004. A framework for managing a portfolio of socially responsible investments. European Journal of Operational Research 153(2): 517-529.

Hamilton, J.T. 1995. Pollution as news: media and stock market reactions to the toxics release inventory data. Journal of Environmental Economics and Management 28(1): 98-113.

Hamilton, S., H. Jo, and M. Statman. 1993. Doing Well While Doing Good? The investment performance of socially responsible mutual funds. Financial Analyst Journal 49(6): 62-66.

Heinkel, R., A. Kraus, and J. Zechner. 2001. The effect of green investment on corporate behavior. The Journal of Financial and Quantitative Analysis 36(4): 431-449.

Henningsen, C. 1992. Measuring performance of a social portfolio. In The social investment Almanac: a comprehensive guide to socially responsible investing, ed. P.D. Kinder, S.D. Lydenberg, and A.L. Domini, 283-286. New York: Henry Holt and Company.

Hill, R.P., T. Ainscough, T. Shank, and Daryl Manullang. 2007. Corporate social responsibility and socially responsible investing: a global perspective. Journal of Business Ethics 70(2): 165-174.

Hillman, A.J., and G.D. Keim. 2001. Shareholder value, stakeholder management, and social issues: what's the bottom line? Strategic Management Journal 22(2): 125-139. 
Hoepner, A.G.F., and D.G. McMillan. 2009. Research on responsible investment: an influential literature analysis comprising a rating, characterisation, categorisation and investigation, working paper, SSRN.

Hong, H., and M. Kacperczyk. 2009. The price of sin: the effects of social norms on markets. Journal of Financial Economics 93(1): 15-36.

Hong, H., J.D. Kubik, and J.A. Scheinkman. 2012. Financial constraints on corporate goodness, working paper, SSRN.

Risklab. 2009. E.S.G. risk factors in a portfolio context. http://www.risklab.com/Dokumente/Aufsaetze/ HoerterEtAl[10]-ESGRiskFactorsInAPortfolioContext.pdf. Accesses 24 Jan 2013.

Hummels, H., and D. Timmer. 2004. Investors in need of social, ethical, and environmental information. Journal of Business Ethics 52(1): 73-84.

Humphrey, J.E., D.D. Lee, and Y. Shen. 2012. Does it cost to be sustainable? Journal of Corporate Finance 18(3): 626-639.

Hussein, K., and M. Omran. 2005. Ethical investment revisited: evidence from Dow Jones Islamic indices. The Journal of Investing 14(3): 105-126.

Jacob, C.K. 2012. The impact of financial crisis on corporate social responsibility and its implications for reputation and risk management. Journal of Management and Sustainability 2(2): 259-275.

Jegadeesh, N., and S. Titman. 1993. Returns to buying winners and selling losers: implications for stock market efficiency. The Journal of Finance 48(1): 65-91.

Jensen, M.C. 1967. The performance of mutual funds in the period 1945-1964. Journal of Finance 23(2): 389-416.

Jones, R., and Audrey J. Murrell. 2001. Signaling positive corporate social performance. Business and Society 40(1): 59-78.

Judge, W.Q., and Thomas J. Douglas. 1998. Performance implications of incorporating natural environmental issues into the strategic planning process: an empirical assessment. The Journal of Management Studies 35(2): 241-262.

Kahn, R.N., C. Lekander, and T. Leimkuhler. 1997. Just Say No? The investment implications of tobacco divestiture. The Journal of Investing 6(4): 62-70.

Kempf, A., and Peer Osthoff. 2007. The effect of socially responsible investing on portfolio performance. European Financial Management 13(5): 908-922.

Kinder, P.D., and Amy L. Domini. 1997. Social screening: paradigms old and new. The Journal of Investing 6(4): 12-19.

Klaasen, R.D., and C.P. McLaughlin. 1996. The impact of environmental management on firm performance. Management Science 42(8): 1199-1214.

Koellner, T., O. Weber, M. Fenchel, and R. Scholz. 2005. Principles for sustainability rating of investment funds. Business Strategy and the Environment 14(1): 54-70.

Konar, S., and M.A. Cohen. 1997. Information as regulation: the effect of community right to know laws on toxic emissions. Journal of Environmental Economics and Management 32(1): 109-124.

Konar, S., and M.A. Cohen. 2001. Does the market value environmental performance? The Review of Economics and Statistics 83(2): 281-289.

Kreander, N., R.H. Gray, D.M. Power, and C.D. Sinclair. 2005. Evaluating the performance of ethical and non-ethical funds: a matched pair analysis. Journal Of Business Finance and Accounting 32(7\&8): 1465-1493.

Kurtz, L. 1997. No effect, or no net effect? Studies on socially responsible investing. The Journal of Investing 6(4): 37-49.

Kurtz, L., S.D. Lydenberg, and P.D. Kinder. 1992. The domini social index: a new benchmark for social investors. In The social investment Almanac: a comprehensive guide to socially responsible investing, ed. P.D. Kinder, S.D. Lydenberg, and A.L. Domini, 287-322. New York: Henry Holt and Company.

Laufer, W.S. 2003. Social screening of investments: an introduction. Journal of Business Ethics 43(3): $163-165$.

Lewis, A., and Craig Mackenzie. 2000a. Morals, money, ethical investing and economic psychology. Human Relations 53(2): 170-191.

Lewis, A., and C. Mackenzie. 2000b. Support for investor activism among UK ethical investors. Journal of Business Ethics 24(3): 215-222.

Louche, C., and S. Lydenberg. 2006. Socially responsible investment: differences between Europe and United States, working paper, SSRN. 
Lu, J.R., and C.M. Chan. 2012. Religious-based portfolio selection. Review of Financial Economics 21(1): 31-38.

Luther, R.G., J. Matatko, and D.C. Corner. 1992. The investment performance of UK "Ethical" unit trusts. Accounting, Auditing and Accountability Journal 5(4): 57-70.

Lydenberg, S.D., and L. Kurtz. 1992. Researching social performance. In The social investment Almanac: a comprehensive guide to socially responsible investing, ed. P.D. Kinder, S.D. Lydenberg, and A.L. Domini, 203-224. New York: Henry Holt and Company.

Mackenzie, C., and A. Lewis. 1999. Morals and markets: the case of ethical investing. Business Ethics Quarterly 9(3): 439-452.

Mackey, A., T.B. Mackey, and J.B. Barney. 2007. Corporate social responsibility and firm performance: investor preferences and corporate strategies. Academy of Management Review 32(3): 817-835.

Maignan, Isabelle, and David A. Ralston. 2002. Corporate social responsibility in Europe and the US: insights from businesses' self-presentations. Journal of International Business Studies 33(3): 497-514.

Mallin, C.A., B. Saadouni, and R.J. Briston. 1995. The financial performance of ethical investment funds. Journal Of Business Finance and Accounting 22(4): 483-496.

Margolis, J.D., and J.P. Walsh. 2003. Misery loves companies: rethinking social initiatives by business. Administrative Science Quarterly 48(2): 268-305.

McCann, L., A. Solomon, and J.F. Solomon. 2003. Explaining the growth of UK socially responsible investment. Journal of General Management 28(4): 15-36.

McLachlan, J., and J. Gardner. 2004. A comparison of socially responsible and conventional investors. Journal of Business Ethics 52(1): 11-25.

Michelson, G., N. Wailes, S. van der Laan, and G. Frost. 2004. Ethical investment processes and outcomes. Journal of Business Ethics 52(1): 1-10.

Mill, G.A. 2006. The financial performance of a socially responsible investment over time and a possible link with corporate social responsibility. Journal of Business Ethics 63(2): 131-148.

Moskowitz, M. 1972. Choosing socially responsible stocks. Business and Society Review, Spring 1: 71-75.

Moskowitz, M. 1997. Social investing: the moral foundation. The Journal of Investing 6(4): 9-11.

Mueller, S.A. 1991. The opportunity cost of discipleship: ethical mutual funds and their performance. Sociological Analysis 52(1): 111-124.

Ogden, Stuart, and Robert Watson. 1999. Corporate performance and stakeholder management: balancing shareholder and customer interests in the UK privatized water industry. Academy of Management Journal 42(5): 526-538.

Orlitzky, M., F.L. Schmidt, and S.L. Rynes. 2003. Corporate social and financial performance: a metaanalysis. Organisation Studies 24(3): 403-441.

Pasewark, W.R., and M.E. Riley. 2010. It's a matter of principle: the role of personal values in investment decisions. Journal of Business Ethics 93(2): 237-253.

Pava, M.L., and J. Krausz. 1996. The association between corporate social-responsibility and financial performance: the paradox of social cost. Journal of Business Ethics 15(3): 321-357.

Pinner, W. 2003. Ethische investments—Rendite mit "sauberen" Fonds. Wiesbaden: Gabler Verlag.

Prodhan, B. 1995. Ethical conflicts in finance. In Ethical conflicts in finance, ed. A.R. Prindl, and B. Prodhan, 3-29. Oxford: Blackwell.

Renneboog, L., J. Ter Horst, and C. Zhang. 2008. Socially responsible investments: institutional aspects, performance, and investor behavior. Journal of Banking and Finance 32(9): 1723-1742.

Richardson, B.J. 2009. Keeping ethical investment ethical: regulatory issues for investing for sustainability. Journal of Business Ethics 87(4): 555-572.

Rivoli, P. 2003. Making a difference or making a statement? Finance research and socially responsible investment. Business Ethics Quarterly 13(3): 271-287.

Rosen, B.N., D.M. Sandler, and D. Shani. 1991. Social issues and socially responsible investment behavior: a preliminary empirical investigation. The Journal of Consumer Affairs 25(2): 221-234.

Rudd, A. 1981. Social responsibility and portfolio performance. California Management Review 23(4): 55-61.

Saltuk, Y. 2011. Insight into the impact investment market. J.P.Morgan Social Finance Research: 1-30.

Salzmann, O., A. Ionescu-Somers, and U. Steger. 2005. The business case for corporate sustainability: literature review and research options. European Management Journal 23(1): 27-36. 
Sandberg, J. 2008. The ethics of investing: making money or making a difference? In Acta philosophica gothoburgensia 25, ed. H. Malmgren, C. Munthe, I. Persson, and W. Dag, 223-255. Göteborg: Department of Philosophy of the University of Gothenburg.

Sandberg, J., C. Juravle, T.M. Hedesström, and I. Hamilton. 2009. The hzeterogeneity of socially responsible investment. Journal of Business Ethics 87(4): 519-533.

Sauer, D.A. 1997. The impact of social-responsibility screens on investment performance: evidence from the domini 400 social index and domini equity mutual fund. Review of Financial Economics 6(2): 137-149.

Schröder, M. 2004. The performance of socially responsible investments: investment funds and indices. Financial Markets and Portfolio Management 18(2): 122-142.

Schueth, S. 2003. Socially responsible investing in the United States. Journal of Business Ethics 43(3): 189-194.

Schwartz, M.S. 2003. The "Ethics" of ethical investing. Journal of Business Ethics 43(3): 195-213.

Shank, T., D. Manullang, and R.P. Hill. 2005. "Doing Well While Doing Good" revisited: a study of socially responsible firms' short-term versus long-term performance. Managerial Finance 30(8): 33-46.

Sharpe, W.F. 1966. Mutual fund performance. The Journal of Business 39(1 part 2: supplement on security prices): 119-138.

Social Investment Forum Foundation. 2010. Report on socially responsible investing trends in the United States. Washington: Social Investment Forum Foundation.

Solomon, J., A. Solomon, and S. Norton. 2002. Socially responsible investment in the UK: drivers and current issues. Journal of General Management 27(3): 1-14.

Sparkes, R. 2001. Ethical investment: whose ethics, which investment? Business Ethics: A European Review 10(3): 194-205.

Sparkes, R. 2002. Socially responsible investment: a global revolution. England: Wiley.

Sparkes, R., and Christopher J. Cowton. 2004. The maturing of socially responsible investment: a review of the developing link with corporate social responsibility. Journal of Business Ethics 52(1): 45-57.

Statman, M. 2000. Socially responsible mutual funds. Financial Analyst Journal 56(3): 30-39.

Teoh, S.H., I. Welch, and C. Paul Wazzan. 1999. The effect of socially activist investment policies on the financial markets: evidence from the South African boycott. The Journal of Business 72(1): 35-89.

Teper, J.A. 1992. Evaluating the cost of socially responsible investing. In The social investment Almanac: a comprehensive guide to socially responsible investing, ed. P.D. Kinder, S.D. Lydenberg, and A.L. Domini, 340-349. New York: Henry Holt and Company.

Tippet, J. 2001. Performance of Australia's ethical funds. The Australian Economic Review 34(2): $170-178$.

Tobin, J. 1969. A general equilibrium approach to monetary theory. Journal of Money, Credit and Banking 1(1): 15-29.

Travers, F.J. 1997. Socially responsible investing on a global basis: mixing money and morality outside the US. The Journal of Investing 6(4): 50-56.

Treynor, J.L. 1965. How to rate management of investment funds. Harvard Business Review 43(1): $63-75$.

Utz, S., M. Wimmer, M. Hirschberger, and R.E. Steuer. 2014. Tri-criterion inverse portfolio optimization with application to socially responsible mutual funds. European Journal of Operational Research 234(2): 491-498.

Verschoor, C.C. 1998. A study of the link between a corporation's financial performance and its commitment to ethics. Journal of Business Ethics 17(13): 1509-1516.

Waddock, S.A., and Samuel B. Graves. 1997. Finding the link between stakeholder relations and quality of management. The Journal of Investing 6(4): 20-24.

Wimmer, M. 2013. ESG-persistence in socially responsible mutual funds. Journal of Management and Sustainability 3(1): 9-15.

Wood, D.J., and R.E. Jones. 1995. Stakeholder mismatching: a theoretical problem in empirical research on corporate social performance. The International Journal of Organizational Analysis 3(3): 229-267.

Wright, P., and S.P. Ferris. 1997. Agency conflict and corporate strategy: the effect of divestment on corporate value. Strategic Management Journal 18(1): 77-83. 